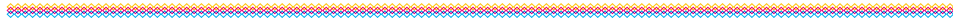

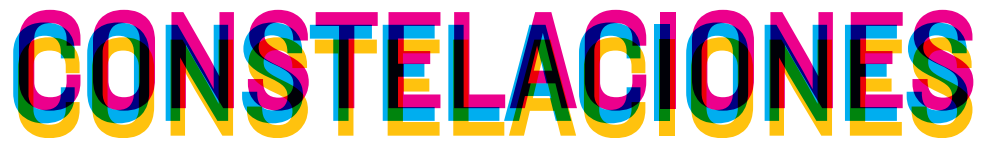

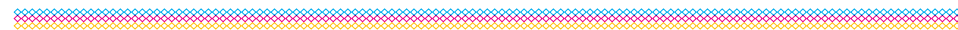


CONSTELACIONES nº6, mayo 2018

Revista de Arquitectura de la Universidad CEU San Pablo

Architecture Magazine of CEU San Pablo University

Periodicidad anual

Annual periodicity

COMITÉ DE REDACCIÓN EDITORIAL COMMITTEE

\section{Dirección Directors}

Juan García Millán

Santiago de Molina

Jefa de Redacción Editor in Chief

Covadonga Lorenzo Cueva

Secretario de Redacción Editorial Clerk

Rodrigo Núñez Carrasco

Maquetación y producción Design and production

Clara Martínez-Conde Rubio

Julia Ruiz-Cabello Subiela

Responsable Web Web Page Manager

María Isabel Castilla Heredia

Diseño Original Original Design

Juan Roldán Martín

\section{CONSEJO EDITORIAL EDITORIAL BOARD}

Beatriz Colomina. School of Architecture, Princeton University, New Jersey

Carmen Díez Medina. Escuela de Ingeniería y Arquitectura, Universidad de Zaragoza

María Antonia Frías Sargadoy. Escuela Técnica Superior de Arquitectura, Universidad de Navarra

Juan Miguel Hernández Léon. Escuela Técnica Superior de Arquitectura, Universidad Politécnica de Madrid Juan José Lahuerta Alsina. Escuela Técnica Superior de Arquitectura, Universidad Politécnica de Cataluña, Barcelona Eduardo Leira Sánchez. Ex director del Plan General de Ordenación Urbana, Madrid

Joaquín Medina Wamburg. Facultad de Aquitectura Diseño y Urbanismo, Universidad de Buenos Aires

Zaida Muxí Martínez. Escuela Técnica Superior de Arquitectura, Universidad Politécnica de Cataluña, Barcelona José Joaquín Parra Bañón. Escuela Técnica Superior de Arquitectura, Universidad de Sevilla

Víctor Pérez Escolano. Escuela Técnica Superior de Arquitectura, Universidad de Sevilla

Fernando Pérez Oyarzún. Escuela de Arquitectura y Diseño, Pontificia Universidad Católica, Santiago de Chile

Judith Sheine. School of Architecture and Allied Arts, University of Oregon, Portland

Andrés Walliser Martínez. Global Design, New York University, Nueva York

ISSN 2340-177X

Depósito legal M-13872-2013

(c) de los textos, sus autores

(c) de las imágenes autorizadas

(c) Revista Constelaciones

๑) Escuela Politécnica Superior, Universidad CEU San Pablo

Universidad CEU San Pablo

Escuela Politécnica Superior

Urbanización Montepríncipe, s/n

Alcorcón, 28925. Madrid (España)

constelaciones@eps.ceu.es

www.uspceu.es

www.revistaconstelaciones.wordpress.com

Edición Edition

Fundación Universitaria San Pablo CEU

Madrid, España

Impresión Printing

VA Impresores

Impreso en España Printed in Spain

Distribución Distribution

CEU Ediciones

\author{
INDEXACIÓN INDEXING \\ Índices Index \\ Latindex \\ Avery Index \\ ErihPlus \\ MIAR
}

Bases de datos Data bases

Dialnet

Índices en evaluación Evaluation Index

Web of Science

Scopus

Dulcinea

EBSCO

Sherpa Romeo

Los textos que componen Constelaciones se obtienen mediante convocatoria pública. Para que los trabajos recibidos entren en el proceso de selección de los artículos a publicar deben ser trabajos originales no publicados anteriormene, con una extensión recomendada de 3.000 palabras, título, resumen (un máximo de 150 palabras) y palabras clave (un mínimo de cuatro palabras), en español y en inglés. Tras haber cumplido estos requisitos (y los correspondientes incluidos en las normas editoriales de la revista, disponibles para consulta en formato digital desde el comienzo de la convocatoria), tiene lugar un proceso de revisión y evaluación de los artículos previa aceptación de los mismos para su publicación. Para acometer dicho proceso, y con el fin de asegurar la calidad de los contenidos, la revista Constelaciones recurre a evaluadores externos a la institución editora y anónimos (cada artículo es evaluado por dos de ellos) encargados de someter a crítica los mismos. Todos los artículos de investigación publicados en esta revista han pasado por dicho proceso. La recepción de artículos se extendió hasta el 30 de septiembre de 2017. Texts included in Constelaciones are obtained by public announcement. Only original papers that have not been previously published will be included in the process of selection of articles. They should not exceed 3.000 words and should include a title, an abstract (no more than 150 words) and keywords (a minimum of four words), in Spanish and English. After having fulfilled these requirements (and those included in magazine editorial standards, available for consultation from the beginning of the Call for Papers), occurs a process of review and evaluation of articles upon acceptance of them for publication. To undertake this process, and in order to ensure the quality of the contents, Constelaciones turns to external and anonymous evaluators to the institution (each article is evaluated by two of them) responsible for the critic. All the articles published in this journal have undergone this process. The deadline for reception was extended until September 30, 2017.

Todos los derechos reservados. Esta publicación no puede ser reproducida, ni en todo ni en parte, ni registrada, ni transmitida, ni almacenada en ninguna forma ni por ningún medio, sin la autorización previa y por escrito del equipo editorial. En este número se han utilizado algunas imágenes de las que no se ha podido identificar al propietario de los derechos. En estos casos hemos entendido que las imágenes son de libre uso. En caso de identificar alguna de estas imágenes como propia, por favor, póngase en contacto con la redacción de Constelaciones. Los criterios expuestos en los diversos artículos de la revista son responsabilidad exclusiva de sus autores y no reflejan necesariamente los que pueda tener el equipo editoral. El equipo editorial de la revista no se responsabiliza de devolver la información enviada a la redacción a no ser que se le solicite expresamente. All rights reserved. This publication cannot be reproduced, in whole or in part, nor registered, transmitted or stored in any form or by any means, without the written permission of the Editorial team, In this issue some images were used without knowing the owner of the rights. In these cases, we have understood that the images are free of use. In case you identify shared by the editors of this journal. The publisher don't take responsibility for returning submitted material which is not expressly requested. 


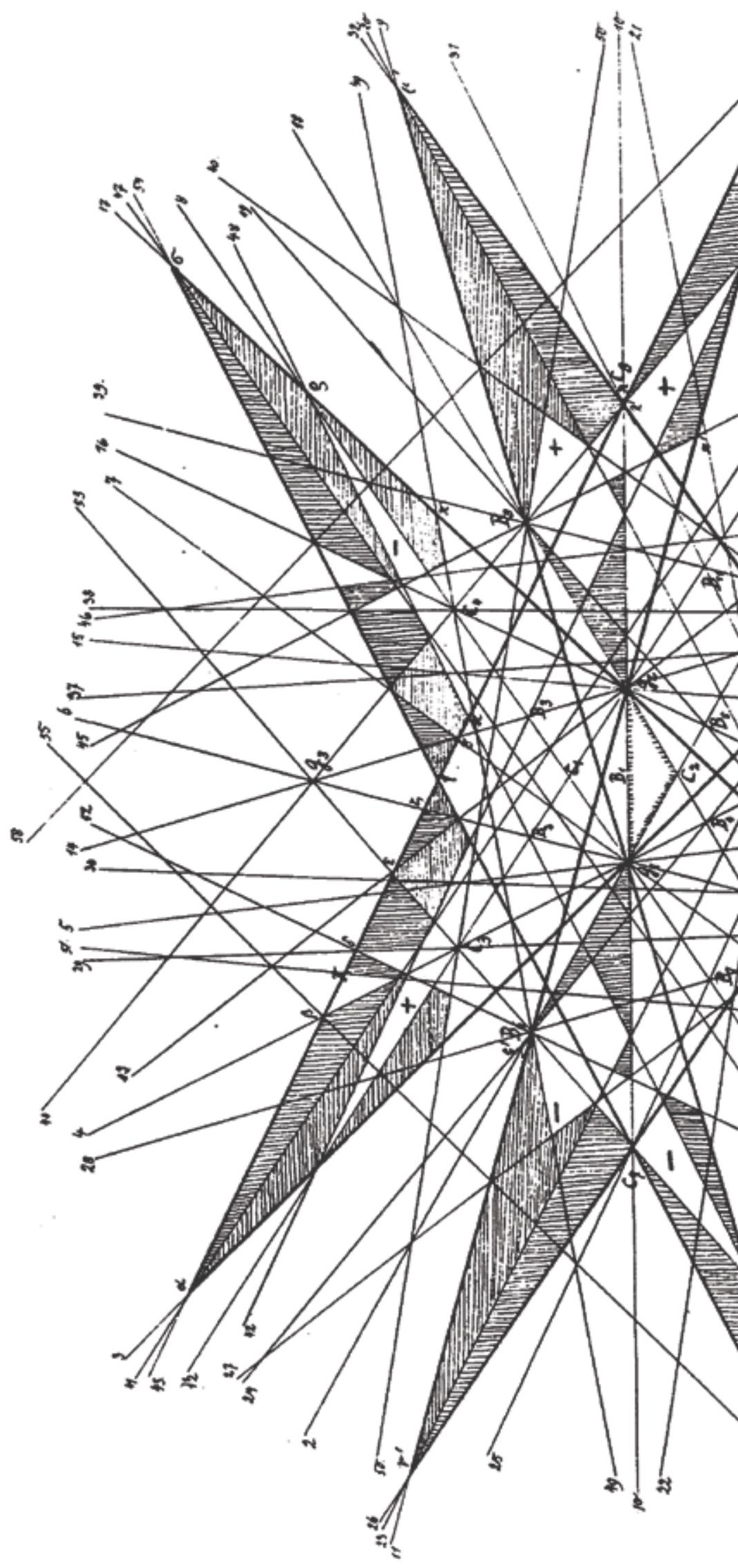




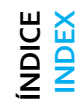

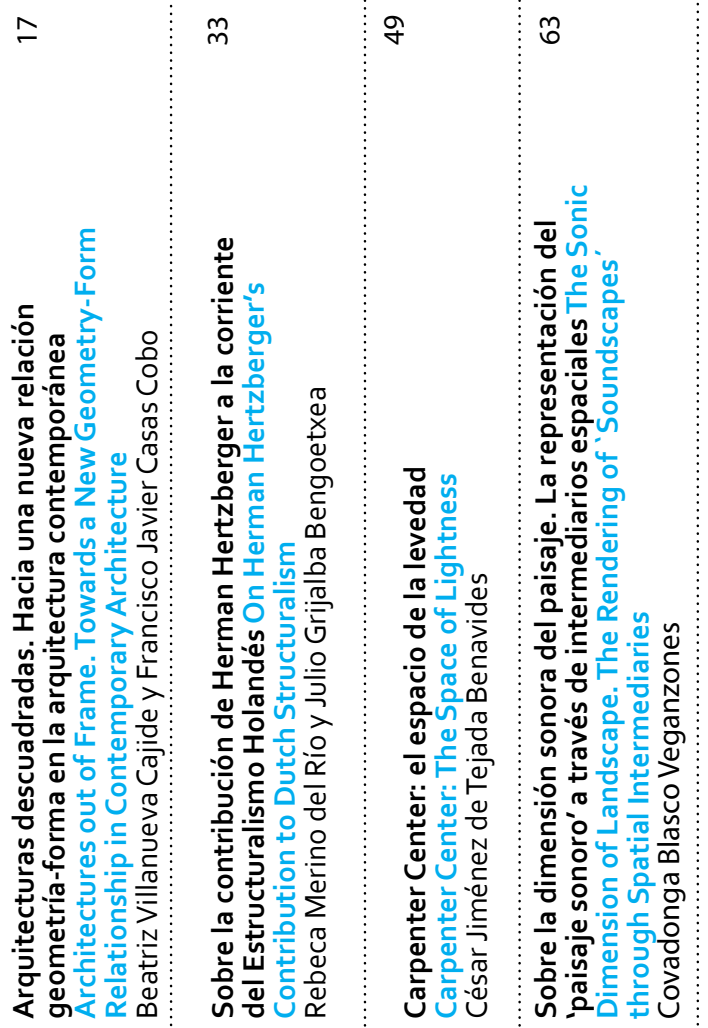

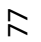

ต

$\leftleftarrows$

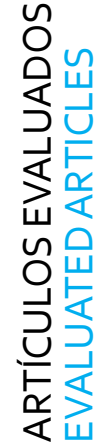

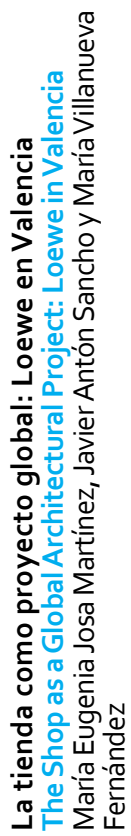

윰 可

틈응

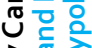

울을

I0

율

동

능

잉이

용요

ब雨

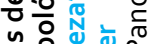

은음

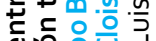

넌은 을겅

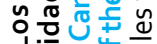

능뭉ㅎㅇㅇㅇㅇ

荇

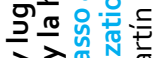

入入⿻

준

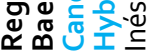
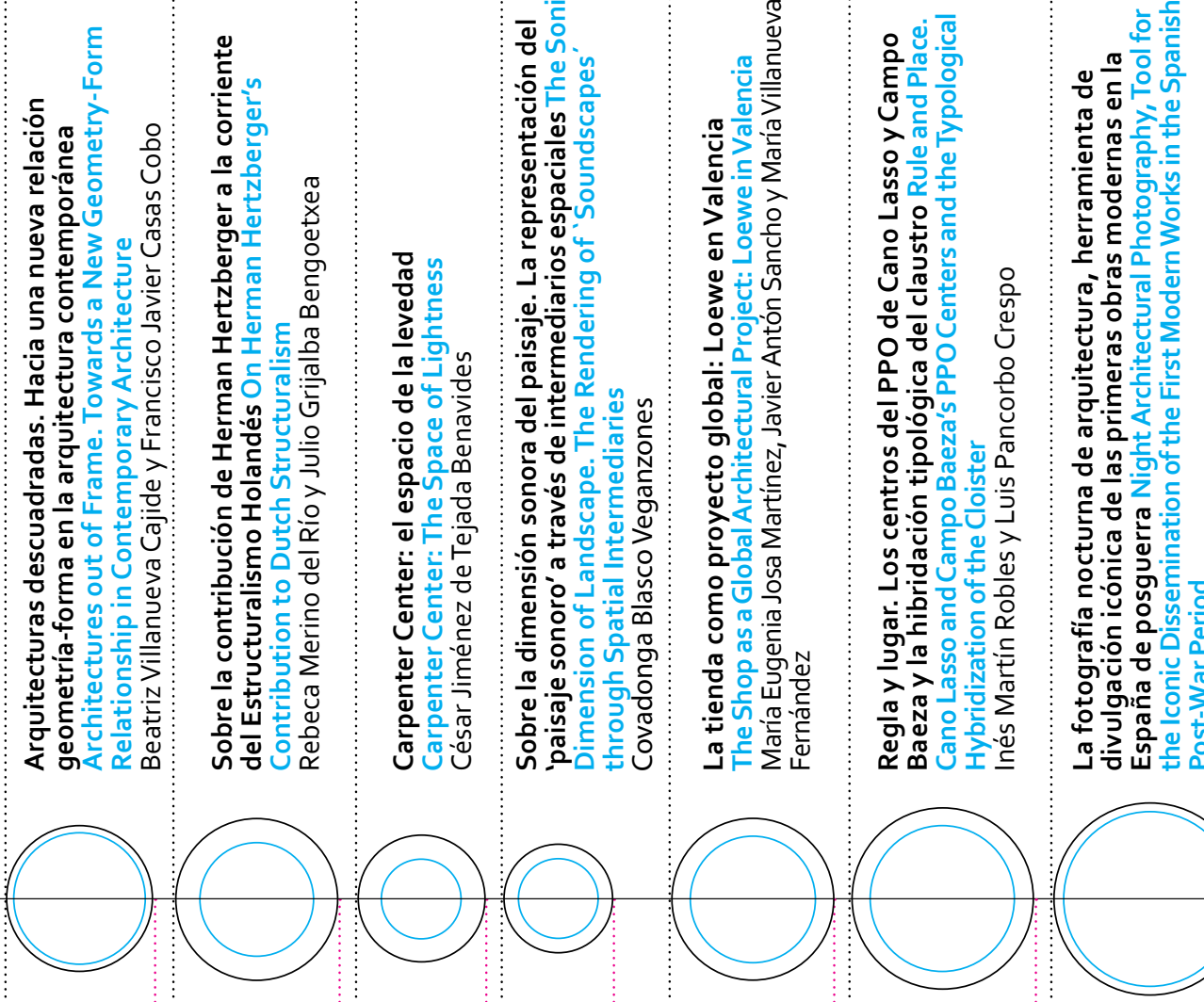

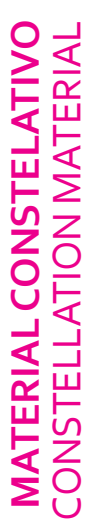

岂㟧

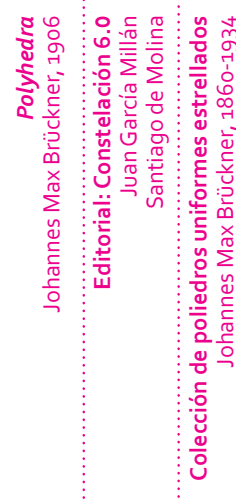

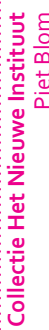
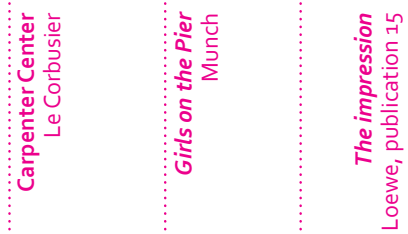

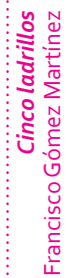

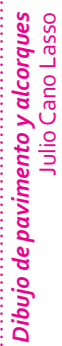

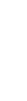

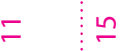

$\bar{m}$

ร

ธ

옹 


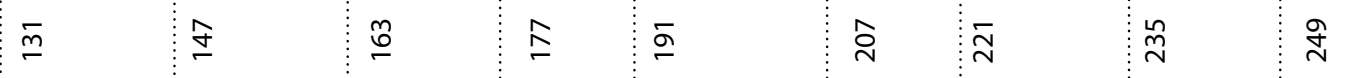

ह단

竞:

을 응

$\frac{\pi}{2} \cup$

을

约

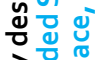

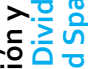

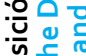

负

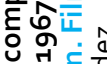

중

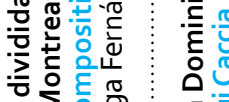

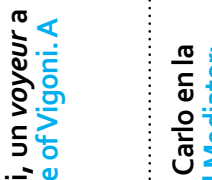

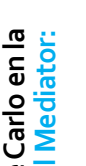

हें

ดั ชั

은 흥영

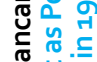

ชั่

ए

ธิ่

过 벙

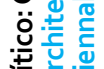

능는

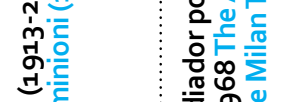

ชั0

हूष

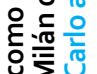

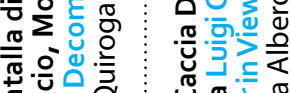

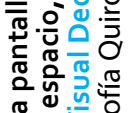

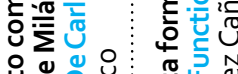

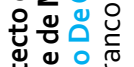

껀

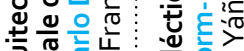

:

혼든 은

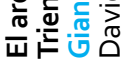

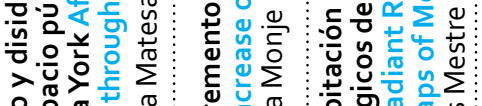

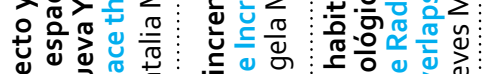

选守之光艺

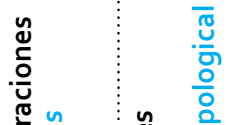

는 흔

กำ $\frac{1}{0} \div$

ถั

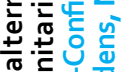

入ว 일

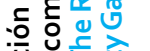

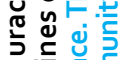

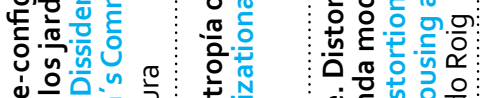

๙

.ํำ $\stackrel{0}{0}$

난.

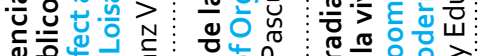

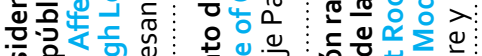

능

త $>\boldsymbol{>}$

ง๋

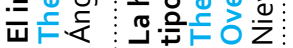
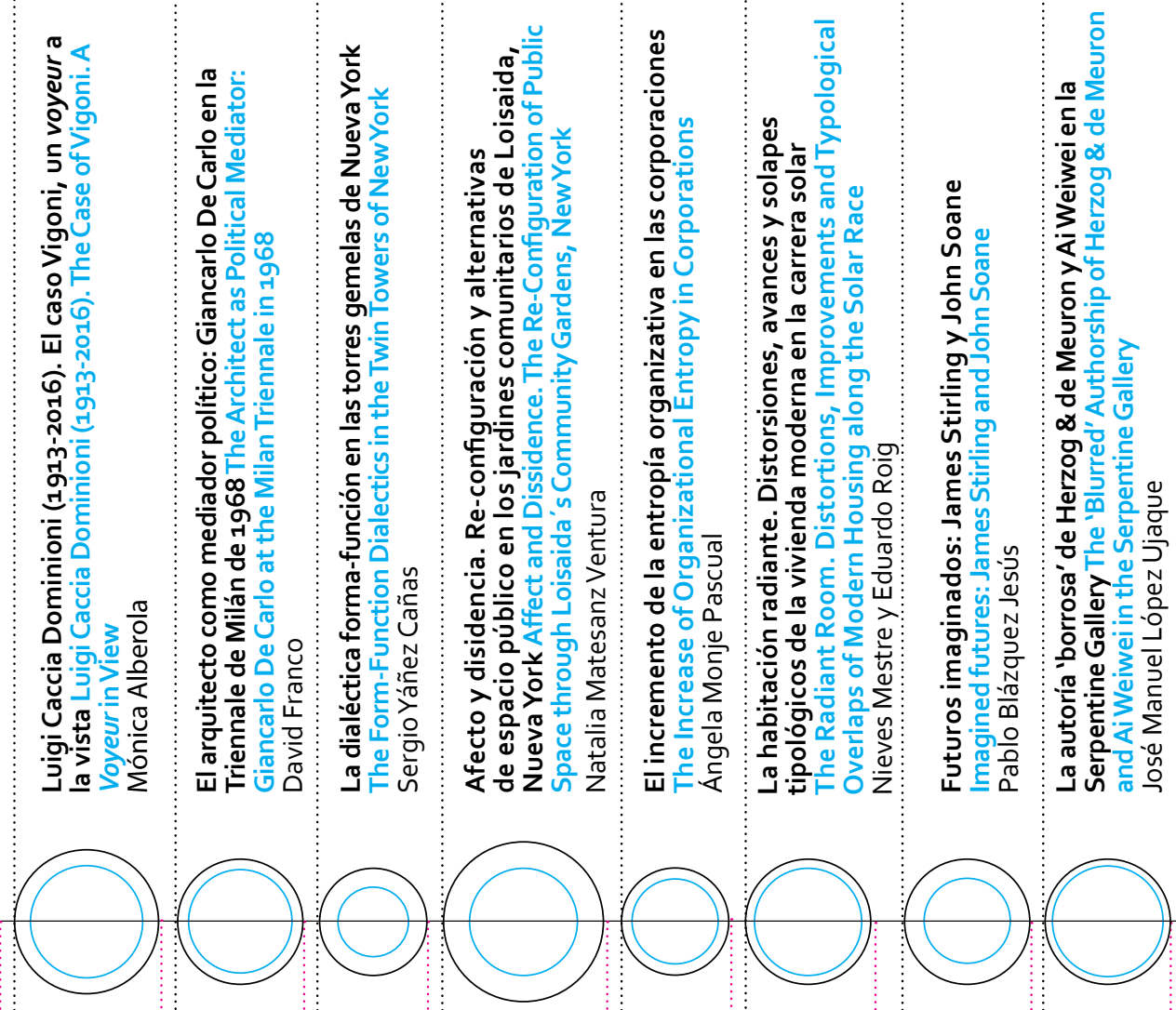

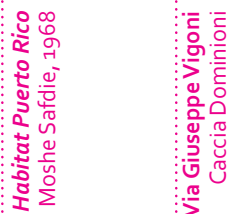

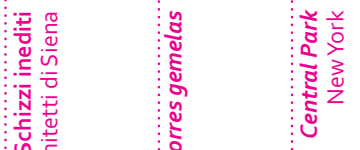

$\sum_{2}^{2}$

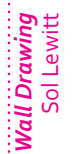

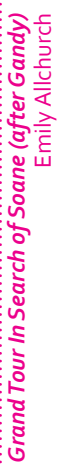

ำ

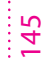

$\stackrel{\circ}{\stackrel{n}{2}}$

$\infty$

ํํำ

$\stackrel{N}{\sim}$

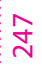

융 గ 


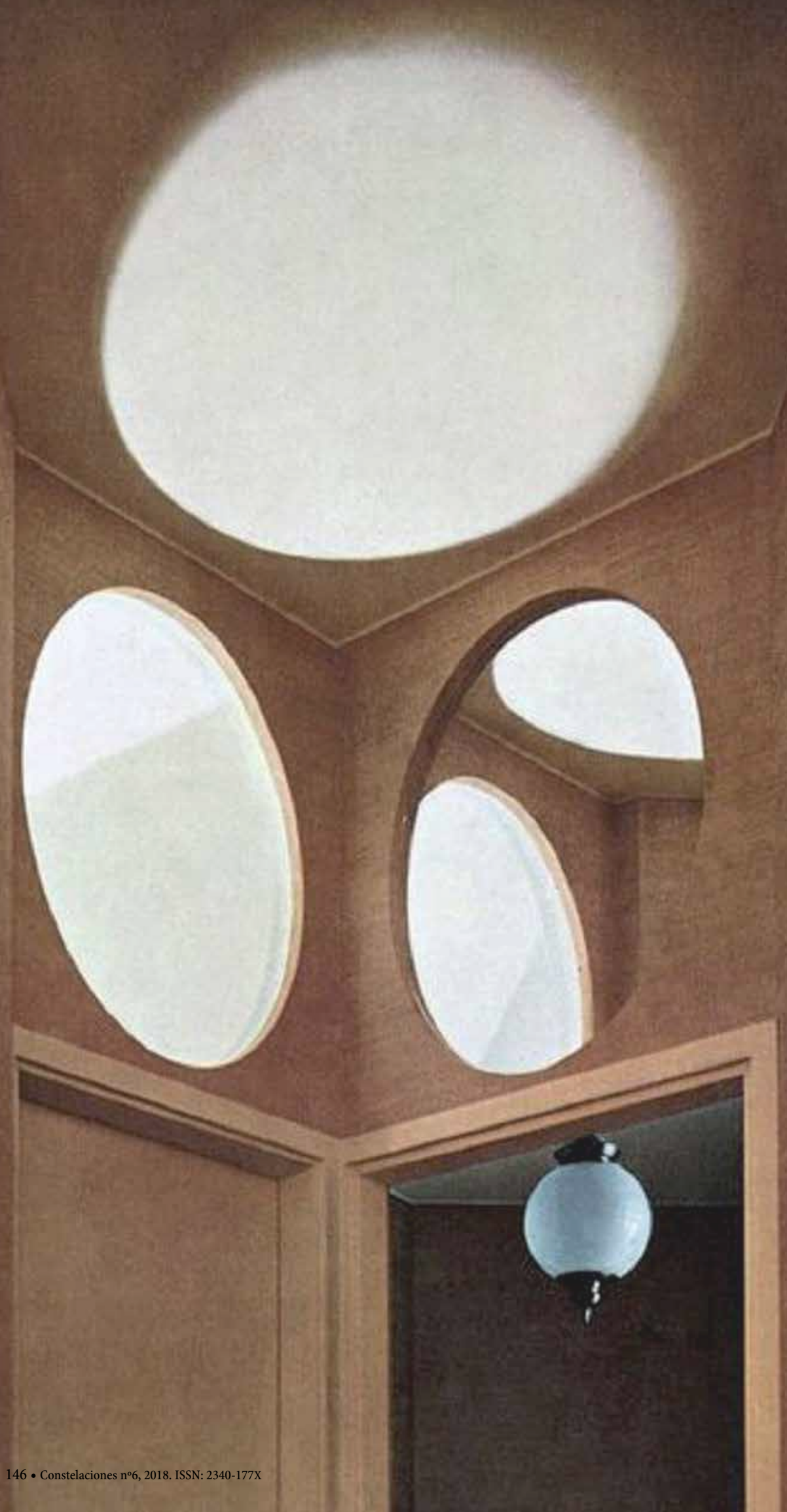




\title{
Luigi Caccia Dominioni (1913-2016). El caso \\ Vigoni, un voyeur a la vista Luigi Caccia \\ Dominioni (1913-2016). The Case of Vigoni. A Voyeur
} in View

\author{
Mónica Alberola \\ Escuela Técnica Superior de Arquitectura, Universidad Politécnica, Madrid \\ Traducción Translation Noemí García Millán
}

\section{Palabras clave Keywords}

Siglo xx, arquitectura contemporánea, vivienda colectiva, Milán, Luigi Caccia Dominioni

20th Century, contemporary architecture, collective housing Milan, Luigi Caccia Dominioni

\section{Resumen}

El arquitecto milanés Luigi Caccia Dominioni trabajó en su ciudad, siempre desde el compromiso con la arquitectura y la profesión. El presente artículo se centra en la presentación y el estudio de uno de sus edificios residenciales más característicos, el situado en la via Giuseppe Vigoni de Milán. Aunque no se puede entender la obra de este autor con un solo edificio, el caso elegido recoge de un modo especialmente intenso temas transportables, no solo a su propia trayectoria sino, sin duda, a la actualidad arquitectónica. La vigencia y sobre todo la necesidad de retomar el proyecto de viviendas desde unas planimetrías realizadas desde el instinto para el habitar de dentro a fuera, sin buscar el espectáculo como resultado; recuperar también la importancia de la composición y el detalle de las fachadas, sin dejar de lado el fundamental compromiso que tiene la arquitectura con la historia, con la ciudad y con sus ciudadanos.

\section{Abstract}

The Milanese architect Luigi Caccia Dominioni always worked in this city displaying his compromise with architecture and the profession. The present article is centred on the presentation and study of one of his most characteristic residential buildings, located in via Giuseppe Vigoni in Milan. Although the work of this author cannot be understood through just one building, the chosen case nonetheless collects, in an especially intense way, issues transferable not only to his own trajectory but also, without a doubt, to the architectural present. The validity and, above all, the need to recapture the housing project from surveys made on instinct, for the inhabiting from inside to outside, without looking for spectacle as the result, also to recuperate the importance of the composition and detail of facades, without setting aside the fundamental compromise that architecture has with history, with the city and with its occupants. 
Procedente de una familia noble lombarda, Luigi Caccia Dominioni nació en Milán un 7 de diciembre de 1913, el día de Sant 'Ambrogio, el mismo día que Bernini y en el palacio familiar situado en la plaza, (1) justo enfrente de la Basílica del mismo nombre. "[...] estaba escrito, he nacido arquitecto y trabajo para intentar hacer algo bello". (2) En 1931 se inscribió en la Facultad de Arquitectura del Politécnico de Milán, momento en el que en Italia, el debate arquitectónico era especialmente rico. Por un lado, las bases establecidas por el grupo llamado Novecento (Giovanni Muzio, Gio Ponti, Giuseppe de Finetti, etc.), en las que se proponía una especie de vuelta al clasicismo y la 'necesaria' recuperación de un espíritu nacional y por otro, la llegada tardía a Italia del Racionalismo, lo que supuso un nuevo lenguaje autónomo y claramente identificable alejado de las corrientes europeas.

Entre los años 1929 y 1933 las revistas italianas Casabella y Quadrante dan buena muestra de la polémica y de las diferencias entre las dos corrientes ideológicas en arquitectura. La cuestión formal, sostenida en la revista Quadrante, frente a la arquitectura como un servicio, como respuesta a una necesidad concreta defendida en Casabella por su director Giuseppe Pagano. Al mismo tiempo, el régimen fascista estaba buscando una identidad arquitectónica que recuperase el espíritu italiano de la antigüedad para representar al nuevo estado. En cierto modo la encontró, promoviendo la arquitectura moderna en combinación con la arquitectura 'clásica' del novecentismo. La súbita muerte en 1936 de Edoardo Persico, director de la revista Casabella junto a Pagano y uno de los mayores defensores del Racionalismo europeo, marcó el comienzo de la retirada de la arquitectura moderna en Italia. (3) Durante estos años, la dificultad para definirse dentro de las diferentes corrientes hará que los arquitectos italianos busquen otro tipo de oportunidades de trabajo, recurriendo a la construcción de edificios temporales, viviendas privadas, casas populares o a realizar las primeras aproximaciones en el mundo del diseño, lo que supondrá la semilla para su desarrollo por las generaciones posteriores.

La guerra interrumpió la producción arquitectónica. Sin embargo, con el dopoguerra empieza una fase de reflexión y de crítica de la mano de las princi-

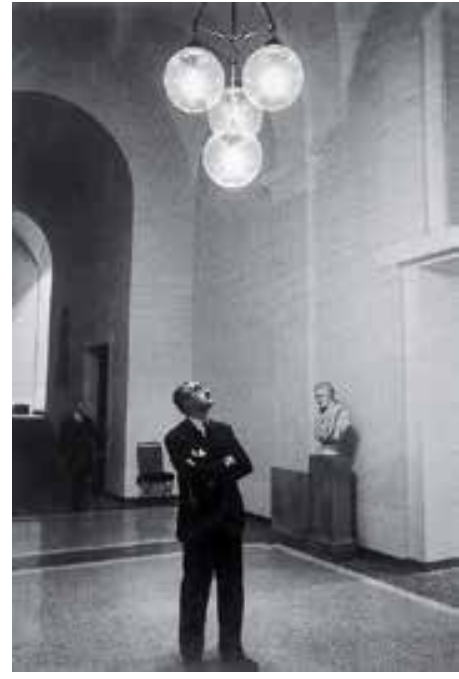

Fig. 1. Luigi Caccia Dominioni observando su lámpara Poltrona

Coming from a noble family in Lombardy, Luigi Caccia Dominioni was born in Milan on December 7th, 1913, the day of Sant'Ambrogio, like Bernini, at the family palace located in the piazza (1) just opposite the basilica with the same name. "[...] it was written, I was born an architect and I work to attempt to make something beautiful”. (2) In 1931 he enrolled at the School of Architecture at the Polytechnic in Milan, at a moment when the architectural debate was especially prolific in Italy. On one hand, the basis established by the group known as 'Nocecento' (Giovanni Muzio, Gio Ponti, Guiseppe de Finetti...), where they proposed a kind of return to classicism and the 'necessary' recovery of a national spirit and, on the other, the late arrival of rationalism to Italy. Which meant a new autonomous language clearly identifiable distanced from European currents.

Between 1929 and 1933 the Italian magazines Casabella and Quadrante provided a good example of this polemic and the differences between the two ideological currents in architecture. The formal question, supported by the magazine Quadrante, as opposed to architecture as a service, as an answer to a specific need defended in Casabella by its director Giuseppe Pagano. At the same time, the fascist regime was looking for an architectural identity that would recover the Italian spirit from ancient past to represent the new state. Somehow the regime found it, promoting modern architecture combined with the 'classic' architecture of 'novecentismo'. The sudden death of Edoardo Persico in 1936, director along with Pagano of the magazine Casabella, and one of the greatest defenders of European rationalism, marked the beginning of the retreat of modern architecture in Italy. (3) During these years the difficulty of marking oneself out within the different currents would compel Italian architects to seek other types of work opportunities, turning to the construction of temporary buildings, private homes, popular housing, or making the first approaches in the world of design which meant the seed for its development by later generations. 
pales revistas. En Milán, Ernesto Rogers retoma la publicación de Casabella, añadiéndole el significativo subtitulo de Continuità y en sus editoriales (4) define el término 'ambiente'. Para Rogers, las preexistencias pertenecen al contexto, por lo tanto considerar el contexto era considerar la historia. Esta posición ética en relación al contexto ha jugado un papel importante en la arquitectura, no carente de críticas. (5) Es pues, en este contexto socio-cultural (6) -con la crisis y la inesperada eclosión de buenos arquitectos italianos y de nuevas ideologías, la influencia de los congresos y de los arquitectos europeos y con la realidad de la Reconstrucción, una tarea tan alentadora como dolorosa- donde comienza la carrera de nuestro autor.

En Milán durante los años cincuenta y sesenta, el crecimiento social y económico de la alta burguesía favorecerá la sintonía entre cliente y arquitecto, lo que permitirá el cuidado por el gusto, recuperando cierto ambiente y estilo de vida adecuado al usuario. Estos años serán, la edad de oro de los arquitectos italianos en materia de vivienda. El arquitecto milanés Luigi Caccia Dominioni, que pertenece a una generación destinada a reconstruir el país justo después de su devastación a causa de los bombardeos aliados, trabaja con el ambiente y la historia desde sus primeras obras; hay que destacar que lo hace algunos años antes de la definición teórica de Ernesto Rogers. Sus primeros proyectos se publican muy temprano y se comentan con éxito en las revistas del momento, mostrándose como un ejemplo a seguir, con el fin de encontrar de nuevo la espiritualidad italiana en el arte y la arquitectura. (7) El método proyectual de Caccia está sin duda relacionado con la realidad de la profesión, la arquitectura entendida como un servicio. No es solo un proceso intelectual, es además instintivo y emotivo, está profundamente ligado a la historia de la arquitectura italiana y a la cultura de la clase aristocrática a la cual pertenece el autor. Está al servicio de sus clientes y de su ciudad, al tiempo que maneja unas pocas y precisas variables y con su catálogo, produce unos ejercicios de estilo, una manera propia y reconocible, un ideal característico de unidad, equilibrio, elegancia y belleza.

El proyecto que aquí se presenta se comenzó a gestar en 1955, finalizándose en 1959. Al terminar la guerra, la calle Giuseppe Vigoni estaba sin urbanizar en su

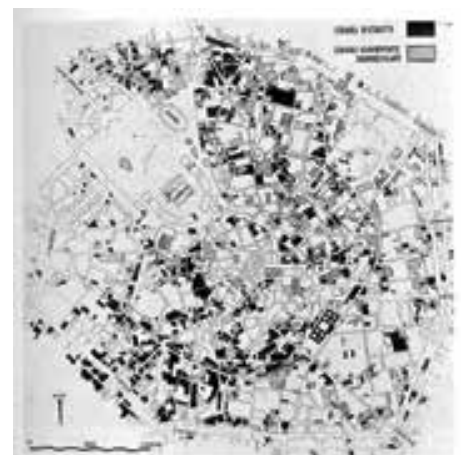

Fig. 2. Colusi, Paolo. Plano de Milán con los edificios afectados por los bombardeos de 1943. Colusi, Paolo. Storia di Milano.

The war interrupted architectural production. However, with the dopoguerra starts a period of reflection and critical appraisal by the main magazines. In Milan, Ernesto Rogers resumed the publication of Continutà and in his editorials (4) he defined the term environment. For Rogers pre-existences belong to the context, therefore considering the context was to consider history. This ethical position in relation to the context has played an important role in architecture not exempt from criticism. (5) It is thus in this socio-cultural context (6) (with the crisis and the unexpected emergence of good Italian architects and new technologies, the influence of conferences and of European architects, and with the reality of the Reconstruction, a task as inspiring as painful) that our author started his career.

In Milan, during the Fifties and Sixties, the social and economic growth of the upper bourgeoisie would favour the concord between client and architect which would allow the nurturing of taste, recovering some atmosphere and life style suited to the customer. These years were the golden era of Italian architects in the field of housing. The architect from Milan, Luigi Caccia Dominioni, who belongs to a generation destined to reconstruct the country just after its devastation due to the allied bombings, worked with the environment and history from his first works. It should be noted that he did so a few years before Ernesto Rogers' theoretical definition. His initial projects were published very early and were successfully commented in the magazines of the time, seen as an example to follow with the aim of finding again the Italian spirituality in art and architecture. (7) Dominioni's method of project is, no doubt, related to the reality of the profession, architecture understood as a service. It is not only an intellectual process, it is also instinctive and emotional, deeply connected to the history of Italian architecture, and to the culture of the aristocratic class to which the author belonged. He was at the 
encuentro con la calle Quadronno y además, algunos de los edificios más próximos al actual número once habían sido bombardeados. (8) El Plan General Urbano de Milán de 1953 recogía la urbanización de parte de la calle, en concreto su lado sur, en el que se planteaba una edificación semi extensiva que preveía un frente continuo de bloques altos; además se reservaba una zona verde pública en el lado Norte con el objetivo de dejar un espacio libre que pusiera en valor el cercano monumento de San Celso. La calle se adapta y rodea con respeto el jardín trasero del monumento, el pequeño parque liberado por el Plan, situado en el encuentro entre las calles Aldo Lusardi y Vigoni, lo que permite la vista de los dos ábsides: el de Santa Maria dei Miracoli del siglo xv y el del Templo de San Celso, con su torre de estilo románico-lombardo construida antes del año 1000. El conjunto presenta un interesante collage arquitectónico generado por la articulación de las traseras de ambas iglesias. Con el proyecto de la calle Vigoni Caccia busca crear un vínculo con los mencionados edificios históricos.

El volumen del edificio asume la normativa del plan; tiene planta rectangular con 26 metros de frente y trece metros de fondo. Con una altura de 27 metros, empieza con un basamento en el que se sitúan los accesos, las ventanas del semisótano y las de la primera planta de viviendas. Los huecos se colocan en el límite de sus alturas: las ventanas superiores enrasadas con la cara inferior de forjado y las inferiores del semisótano, comienzan al ras de la acera. De este modo, las ventanas se alejan de las posibles miradas del peatón, logrando así una mayor privacidad en el interior. El acceso, un gran hueco de cinco metros de altura, se sitúa claramente desplazado respecto al centro, con lo que el ritmo de las ventanas se rompe, lo que deja cuatro huecos a la izquierda y dos a la derecha, colocando debajo del último la puerta del garaje, un paso de apenas dos metros de altura con un curioso mecanismo de apertura. En el interior, una plataforma circular móvil facilita y resuelve las maniobras de los coches y al igual que la puerta nos recuerda la faceta de diseñador de Caccia Dominioni.

En el basamento, lo mural toma protagonismo y parece endurecerse por la proximidad de la calle. Sin embargo, más arriba, en las plantas superiores caracterizadas por sendas terrazas asimétricas que recogen las salidas de los dor-

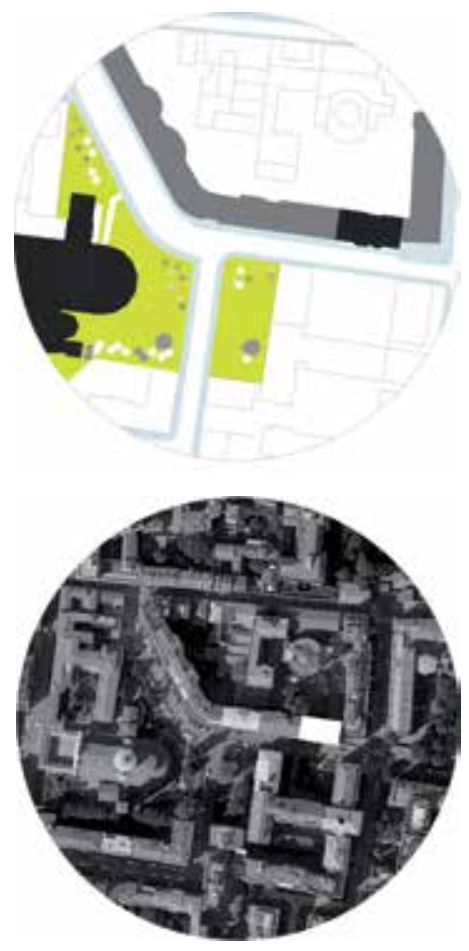

Fig. 3. Plano de situación. Dibujo de la autora. Fig. 4. Emplazamiento. Relación con el monumento de San Celso. Imágenes elaboradas por la autora.

service of his clients and his city and at the same time he managed a few and precise variables, and with his catalogue he produced some style exercises, in his own recognisable way, a characteristic ideal of unity, balance, elegance and beauty.

The project presented here began to take shape in 1955 and was finished in 1959. When the war was over, Giuseppe Vigoni Street was not redeveloped where it crossed Quadronno Street and besides, some of the buildings nearest the present number 11 had been bombed. (8) The General Urban Plan of Milan in 1953 included the development of part of it, specifically its south side, in which a semi-extensive edification was outlined that displayed a continuous front of tall blocks, there was also a public green area reserved in the north side with the objective of leaving an empty space which would allow a clear appreciation of the nearby monument of Saint Celso. The street adjusts itself to, and surrounds with respect, the garden behind the monument, the small park freed up by the Plan, located at the crossing of Aldo Lusardi and Vigoni Streets, which allows the view of both apses, Santa Maria dei Miracoli from the 15th century and the temple of Saint Celso, with its Lombard-Romanesque style tower built before the year 1000. The complex presents an interesting architectural collage generated by the articulation of the rear of both churches. With the Vigoni Street project Caccia sought to create a connection with those historical buildings.

The volume of the building assumed the Plan regulations. It has a rectangular plan of 26 metres at the front and 13 metres in length. With a height of 27 metres it starts with a base on which are located the accesses, the semi-basement windows and the windows of the first floor of the flats. The gaps are placed at the limits of their heights, the upper windows are level with the inferior part of the slab and the lower ones of the semi-basement, start at street level. As a result the windows are 
mitorios, la arquitectura aparece ligera. Las ventanas de los estares se vuelven hacia el oeste buscando la mejor vista y el centro se reserva para producir un vacío con un gran gesto girado y vertical que esconde el tiro de la chimenea, elemento que atraviesa con decisión la cornisa. El lugar toma aquí suma importancia, no se interpreta el espacio urbano como abstracto y universal, sino como específico y único. El proyecto se relaciona con la preexistencia sacra, generadora del alzado, a la vez que busca crear un lugar propio en el interior de las viviendas, los bow-windows atrapan la vista de los ábsides al final de la calle. La disimetría del alzado principal, creada por la decisión de mirar hacia al conjunto de San Celso, caracteriza al edificio, transformándolo en un voyeur que mira, girándose, al foco de interés del barrio.

La fachada trasera, de muy distinta factura a la principal, es a la vez técnica y funcional. El ascensor de servicio discurre por el exterior enseñando su maquinaria y permitiendo, a través de un muro de pavés, el paso de la luz a la escalera de edificio. Las terrazas, por las que se accede directamente a las cocinas, ocupan todo el frente de las dependencias del servicio. En el resto de la fachada se sitúan las ventanas de los dormitorios que dan a Norte. En este caso, un edificio urbano entre medianeras y con poco fondo, el arquitecto se basa en los mismos principios que aplica en otros proyectos de viviendas para resolver la aproximación y la 'búsqueda' de las comunicaciones; sin embargo, aquí los mecanismos de actuación son algo diferentes. El acceso al edificio, como se ha comentado, se encuentra desplazado del centro de la fachada, lo que contribuye a hacer más largo el recorrido interior. Tras pasar las puertas acristaladas aparece una primera escalera que salva el desnivel inicial del portal. Sus peldaños tienen una geometría cóncava en el sentido ascendente, al contrario que muchas de las más famosas escaleras que, de algún modo, expresan con la curva convexa la caída natural de los peldaños. Interpretamos que la de Vigoni quiere ser más amable para el que llega; los escalones abrazan al visitante que entra, le dan la bienvenida invitándole a subir.

La escalera principal, la que da servicio a las plantas superiores, se sitúa en la crujía interior y hasta llegar a ella, en apenas diez metros, se pasa por diferen-
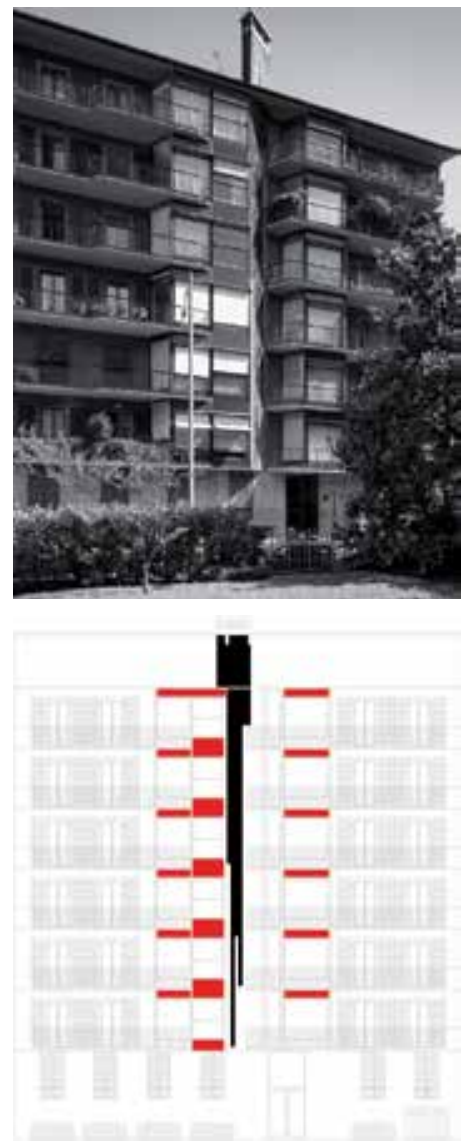

Fig.5. Fachada principal. Fotografía de Marco Introini.

Fig. 6. Alzado principal. Dibujo de la autora.

away from the likely gaze of passers-by, thus achieving greater privacy in the interior. The access, a great gap five metres in height, is clearly placed out of centre, so the rhythm of the windows is broken, which leaves four gaps on the left and two on the right, and placed under the last one is the garage gate, an entrance of barely two metres high with a curious opening mechanism. In the interior a mobile circular platform facilitates and resolves the cars' manoeuvres and, like the door, reminds us of Caccia Dominioni's designer facet.

In the basement the mural takes the role of protagonist and seems to harden through the proximity of the street; however, higher up on the upper floors, characterised by asymmetrical balconies which give access to the bedrooms, the architecture is light. The living room windows turn to face the west seeking the best view, and the centre is reserved to produce a space with a great twisted and vertical gesture that hides the chimney flue, an element that goes through the cornice with determination. Here the site takes huge importance; the urban space is not interpreted as abstract and universal but as unique and specific. The project relates to the sacral pre-existence, which generates the elevation, and at the same time attempts to create its own place in the interior of the homes, the bow-windows catch the view of the apses at the end of the street. The dissymmetry of the main elevation, created by the decision to face the Saint Celso complex, characterises the building, transforming it into a voyeur who, turning round, peeps into the focus of interest of the neighbourhood.

The rear façade, in a very different style from the main façade, is both technical and functional at the same time. The service lift runs up the exterior displaying its machinery and allowing light, through a glass brick wall, to pass through into 
tes ámbitos y de un modo fluido nos desplazamos entre ellos. El ascensor se aparta, se esconde, no le resta protagonismo al recorrido ni a la experiencia de acceso a los pisos. La escalera camufla en su lado derecho el paso hacia el patio trasero donde se sitúa el ascensor de servicio. Los diversos espacios que se suceden en el portal son polígonos irregulares en planta. Su elaborada deformación es clave para la perfección de la profundidad buscada (9) y sus límites, allí donde se encuentra el poché del plano, (10) se macizan y crecen de modo que sirven para trazar discretamente las transiciones a las diferentes piezas de servicio, siempre impertinentes para la sensación buscada por Caccia, que refuerza con el especial diseño de la escalera, la cual bien iluminada y geométricamente 'amable' invita al uso, toma protagonismo y crea la ilusión de acceder a la vivienda de un modo noble, como si de una villa se tratase.

La experiencia espacial y la jerarquía de los accesos son aspectos primordiales en toda obra de arquitectura. Y aunque, es fácil desatenderlos en los proyectos de vivienda, aquí nos encontramos con que tanto la circulación vertical como la horizontal se solucionan en un espacio mínimo, de un modo cuidado y dinámico, aportando unas transiciones rítmicas que suponen una experiencia perceptiva inusual en este tipo de edificaciones. Caccia utiliza la planta como elemento generador del volumen y de la superficie, de manera que produce dos tipos de espacios: el primero visible en la propia planimetría, el real, el que resulta de las características constructivas y programáticas del proyecto. El segundo más complejo y sutil, el que esta encerrado en las reglas del juego que el maestro propone y que sólo aparece una vez construido. Con los dibujos que acompañan a este texto se pretende reflejar como, a través de la planta (de nuevo aparece la importancia del instrumento poché), además de los aspectos volumétricos de la obra, se evidencia la jerarquía entre dos mundos paralelos y el uso diferenciado de los recorridos posibles en una vivienda.

Caccia nos muestra al igual que en los otros proyectos residenciales, que la planta es su medio. En los niveles intermedios se disponen dos apartamentos por planta, uno mayor que el otro, y se puede observar que un veinte por ciento del total de cada vivienda es ocupado por la secuencia de espacios de distribu-

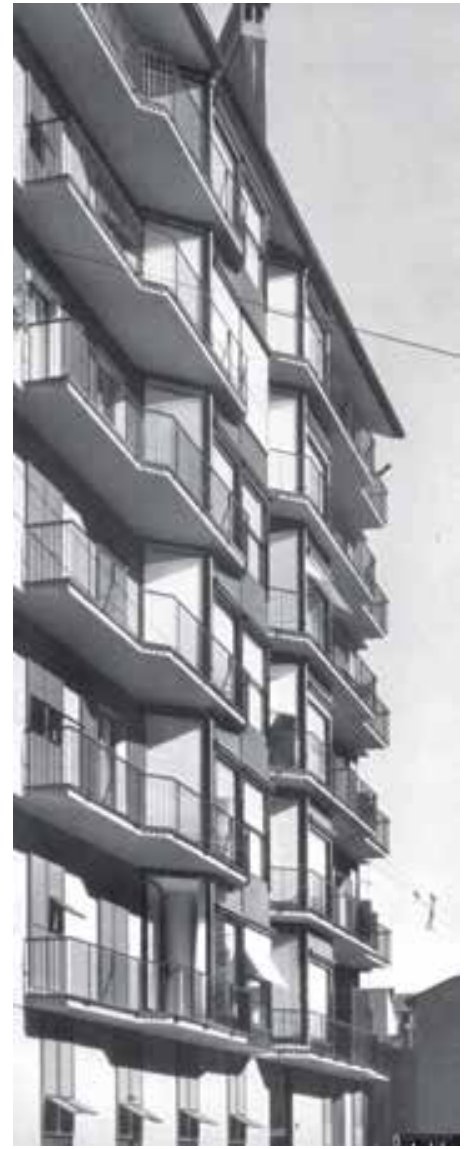

Fig 7. Fotografía de la fachada. Domus 380, 1963.

the staircase of the building. The terraces, from which there are direct accesses to the kitchens, occupy the whole front of the service rooms. The rest of the façade is taken up by the windows for the bedrooms which face north. In this case, an urban building between the adjoining walls of other properties and of no great length, the architect based himself on the same principles he applied in other housing projects to resolve the approximation and the 'search' for communications, but here the intervention mechanisms are a bit different. The access to the building, as I pointed out before, is displaced from the centre of the façade, which contributes to making the interior route longer. After passing through the glass doors the first stairs appear, these compensate the initial height of the hallway. The steps have a concave geometry in the ascending direction, in contrast to many of the most famous stairways which somehow express the natural fall of the steps with the convex curve. We think that Vigoni's stairs want to be friendlier to the person who comes in; they welcome the visitor inviting them to go up.

The main stairway, which gives service to the upper floors, is located in the interior bay, and to get to it, in barely 10 metres, we go through different areas and in a fluid way we move through them. The lift is moved away, hidden, it does not rest prominence to the route or the experience of entering the flats. The stairway camouflages on its right side the way towards the back patio where the service lift is located. The diverse spaces which come one after another in the hallway are irregular polygons in plant. Their elaborated deformation is key for the perfection of the depth sought, (9) and their limits, where the poché of the plane is, (10) become continuous and grow in a way that they are useful to discretely outline the transition to the different service areas, always impertinent for the impression sought by Caccia, which is reinforced 
ción, formando la columna vertebral que estructura y jerarquiza los recorridos internos. Un amplio recibidor nos conduce diagonalmente a los salones y de manera lateral se accece a otro espacio distributivo: un colchón entre la circulación de servicio y la más privada de los dormitorios, reforzando de este modo la diferencia entre el servicio y los habituales en la casa.

Si nos detenemos a analizar el último de los pisos, el que alberga una única vivienda, vemos que la superficie ocupada por los espacios de transición o de distribución es de un treinta por ciento del total. De nuevo, un gran espacio que se deforma acogiéndonos con ricas geometrías, unas ventanas octogonales que comunican visualmente las zonas públicas de la casa y una suerte de espacios que nos conducen, o bien hacia las zonas de servicio o bien hacia los dormitorios. Aquí, en mayor medida que en las plantas inferiores, los recorridos internos son el leitmotiv del diseño de la planta. Caccia consigue no dividir la planta en dos por medio de un rígido corredor; el sistema circulatorio no es un mero pasillo funcional, son estancias amplias y útiles, es donde se desarrolla parte de la vida de los usuarios de la casa. Son estas acciones, las historias y los sucesos que allí ocurren, las que desvelan un espacio generalmente invisible que ahora se convierte en visible.

La percepción de esta espina dorsal es del todo cambiante. Hay un esqueleto estructural, el funcional, el que podemos describir según a dónde nos lleve y qué estancias comunique y sin embargo, la percepción que tenemos en esos espacios es muy heterogénea. Por un lado, las transiciones entre las piezas se resuelven según el Raumplan de Loos, especificando y cualificando cada uno de los diferentes espacios. Por otro lado, se crea la ilusión óptica de que los tabiques son muros gruesos utilizando varios recursos: las esquinas se achaflanan, los armarios ocupan y definen los límites como parte integral de la arquitectura y los paños se decoran con pinturas oníricas y con ricas telas, camuflando de esta manera algunas de las 'molestas' puertas. Todo ayuda a completar la compleja geometría de estos espacios en pos de adquirir mayor relieve a las estancias principales, aquellas que ocupan la crujía hacia la calle.

with the special design of the stairs that are well illuminated and geometrically 'friendly' inviting use, taking prominence and creating the illusion of entering the flats in a noble way, as if it were a villa.

The spatial experience and the hierarchy of the accesses are primordial aspects in every work of architecture. And although it is easy to disregard them in housing projects, here we find that both the vertical and the horizontal circulation are solved in a minimum space, in a careful and dynamic way, providing rhythmical transitions which create an unusual perceptive experience in this type of edifications. Caccia used the plan as an element generator for volume and surface. So it produces two types of spaces: the first visible in the surveying itself, the real one, the one resulting from the constructive and programmatic characteristics of the project. The second, more complex and subtle, the one that is locked in the game rules which the master proposes and which only appear once it is built. With the drawings that accompany this text, we want to reflect how through the plan (again the poché instrument appears) as well as the volumetric aspects of the work, the hierarchy between two parallel worlds is made evident and so is the differentiated use of the possible routes in a home.

Caccia shows us, just as in the other residential projects, that the plan is his means. In the intermediate levels there are two apartments per floor, one bigger than the other, and we can see that 20 per cent of the total of each home is occupied by the sequence of distribution spaces, forming the vertebral column that gives structure and hierarchy to the internal routes. An ample hall diagonally take us to the living areas and in a lateral way we access another distributive space, a cushion between the service circulation and the more private bedrooms, thus reinforcing the difference between the service and the house residents. 

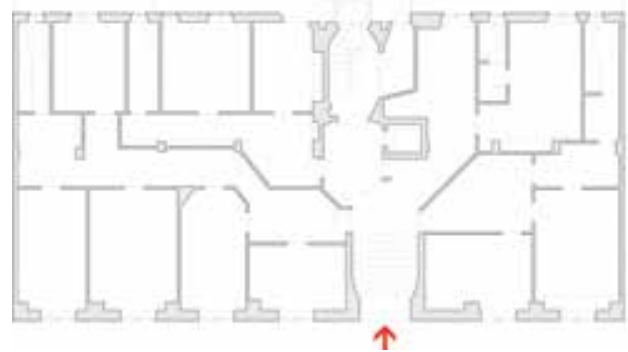

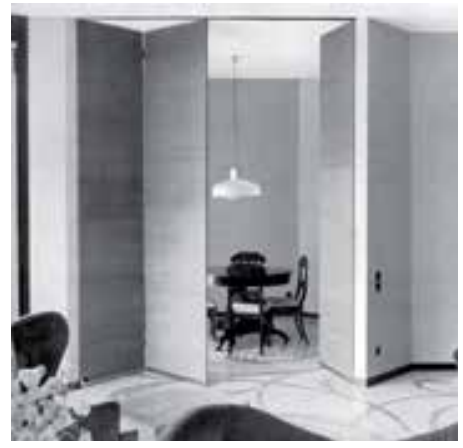

El gran vestíbulo central se comunica visualmente a través de los huecos octogonales con varias salas: la de juegos y la de estar y además, sirve para jerarquizar los distintos recorridos. Girando a la izquierda desde el acceso, un gracioso aunque perturbador distribuidor comunica el comedor con la cocina y las dependencias de servicio. Las paredes, las puertas y los armarios de este espacio están pintadas representando un paisaje continuo, de manera que al no existir molduras ni otras referencias se pierde el sentido de la orientación. Una puerta corredera oculta que sigue la curva del tabique nos da paso al comedor de planta circular. En dicha estancia se crea la ilusión de estar en un espacio exterior, hemos entrado a través del 'jardín' pintado del distribuidor previo. Además, la sala gana una altura convirtiéndose en una estancia cilíndrica a la que se asoma, desde el ático, un balcón, que de nuevo hace referencia a estar en un espacio exterior. En los bordes se sitúan las chimeneas, los armarios o la escalera, lo que le sirve para aumentar la percepción de la magnitud de los muros. Una nueva pieza de transición situada en fachada la comunica con dos estancias de día de la vivienda.

Caccia utiliza varios mecanismos para recrear un ambiente noble y palaciego. Reserva la fachada para colocar las estancias principales, una serie de habitaciones conectadas a través de una sucesión de puertas, colocadas de tal modo que resultan unas estancias enfilade. (11) Una nueva ruta más, noble y privada,

Fig. 8. Planta baja y esquema de acceso. Dibujos de la autora.

Fig. 9. Vista interior del comedor. Planta tipo. Domus 380, 1963.

If we stop to analyse the last floor, where there is only one apartment, we see that the surface occupied by the transition or distribution spaces is 30 per cent of the total. Again, a big space that is deformed welcomes us with rich geometries, octagonal windows which visually communicate the public areas of the house, and a type of spaces that take us to the service areas or to the bedrooms. Here, to a greater extent than on the lower floors, the internal routes are the leitmotiv of the plan design. Caccia managed not to divide the plan into two through a rigid corridor, the circulatory system is not a mere functional passageway, it becomes ample and useful rooms where part of the life of the occupants of the house can take place. It is these actions, stories and events that happen there which reveal a space generally invisible that now becomes visible.

The perception of this dorsal spine definitely changes. There is a structural skeleton, functional, which we can describe according to where it take us and which rooms connect but the perception we have of these spaces is very heterogeneous. On one hand, the transitions between rooms are resolved according to Loos' Raumplan, specifying and qualifying each one of the different spaces. On the other, it creates the optical illusion that the partition walls are thick walls using several means: the corners are chamfered, the wardrobes occupy and define the limits as an integral part of architecture and the wall panels are decorated with oneiric paintings and rich fabrics, thus camouflaging some of the "annoying" doors. Everything helps to complete the complex geometry of these spaces in pursuit of giving more importance to the main rooms, those that occupy the bay towards the street.

The great central hall is visually connected through the octagonal spaces to several rooms: the games room and living room, and also helps to organise hierarchically the different routes. Turning left from the entrance, a charming but disconcerting 
que conecta las dependencias 'sociales' de la vivienda, de uso más pausado y que corresponde a la lógica de "la pompa y el aparato", frente a la "eficacia y discreción" de los recorridos internos. (12) Al final de la visual se coloca la chimenea que da calor al dormitorio principal, al que también se accede desde la zona de noche a través de su propio vestíbulo de armarios. Los límtes de las habitaciones están ocupados por chimeneas, ventanas interiores, puertas o por bow-windows, lo que genera diferentes situaciones de uso que reflejan una útil ambigüedad de las piezas: la habitación multifuncional. (13) El uso y la posible ubicación de los muebles queda sujeta a la ocupación de los límites por estos elementos que forman parte de la arquitectura. La flexibilidad aquí es perceptiva, no se trata de tabiques móviles, ni de una planta libre, sino de la posibilidad de disponer de varios ambientes que aseguren un grado de bienestar y de disfrute del calor de las chimeneas, de la luz y de las vistas.

No cabe duda de que, en toda obra residencial, la planta es el elemento fundamental del proyecto. Sin embargo, Caccia también nos enseña la importancia del detalle en arquitectura. Su experiencia como diseñador y su interés por
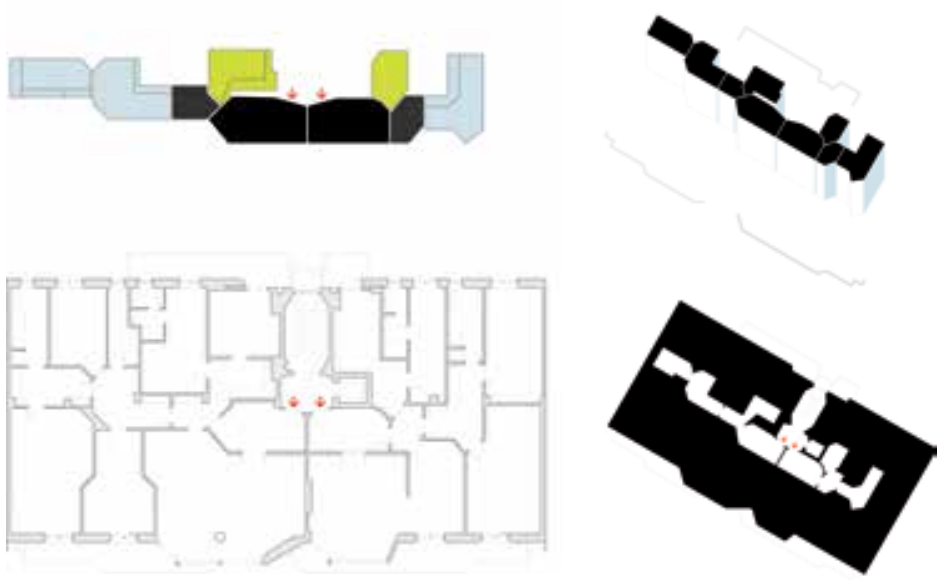

Fig. 10. Planta tipo y esquema de espacios de distribuición. Dibujos de la autora.

Fig. 11. Vista del interior de la planta sexta. Domus 380, 1963.

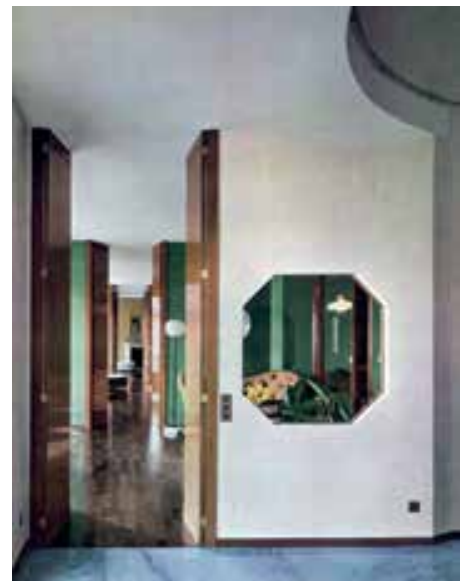

hall connects the dining room to the kitchen and the service rooms. The walls, doors and cupboards of this space are painted to represent a continuous landscape, so that we lose our sense of orientation because there are no mouldings or any other references. A hidden sliding door that follows the curve of the parting wall takes us to the circular plan dining room. In this room there is the illusion of being in an exterior space, we have come in through the painted 'garden' in the hallway, and also the room gains height becoming a cylindrical room in which a balcony overhangs from the attic, which again is a reference to being in an exterior space. On the perimeters are the chimneys, cupboards or the stairway, which helps to increase the perception of the magnitude of the walls. A new transition room located by the façade connects it to two day rooms in the house.

LCD used different mechanisms to recreate a noble and palatial atmosphere. He reserved the façade for the main rooms, a series of rooms connected through a succession of doors placed in such a way that they become enfilade rooms (11). Another new route, noble and private, which connect the 'social' rooms of the home, one of more unhurried use, and which corresponds to the logic of "splendour and public", in opposition to "efficiency and discretion" of the internal routes. (12) At the end of the aspect is the hearth which keeps warm the main bedroom, to which there is also access from the night area through its own hall of wardrobes. The limits of the rooms are occupied by fireplaces, interior windows, doors or bow-windows, which generate different situations of use that reflect a useful ambiguity of the rooms: the multifunctional habitation. (13) The use and possible position of the furniture is subjected to the occupation of the limits by these elements that are part of the architecture. Here, flexibility is perceptive; it is not about mobile partition walls, or an open plan, but the possibility of having several ambiances which assure a level of wellbeing and enjoyment of the warmth of the hearths, the light and the views. 
cuestiones funcionales y de durabilidad le mantiene cerca de los oficios. Se involucra en todo el proceso, cambiando y asumiendo sus errores durante la ejecución, dando un servicio cuidado al cliente, una preocupación que va más allá de la obra en sí. La construcción del edificio es sólida y ligera a la vez. Por encima del basamento de piedra de conglomerado lombardo encontramos varios tipos de cierre, dependiendo de si dan los dormitorios que ocupan los extremos de la fachada o los estares de cada uno de los apartamentos situados en el centro y separados por el potente plano de la chimenea. El primero es un muro, podríamos decir tradicional, de cuarenta centímetros de espesor y acabado en revoco marrón, interrumpido por las salidas de los dormitorios a las terrazas. Dichos huecos se encuentran remarcados por unas embocaduras en piedra volcánica cuya geometría, por un lado, permite recoger la máxima luz abriéndose a los laterales y por otro lado, al cerrarse, recupera la vertical, lo que asegura una buena protección contra el agua de lluvia en su parte superior. Las contraventanas de madera pintada completan estos paños, que quedan perfectamente modulados por la posición abierta de estas.
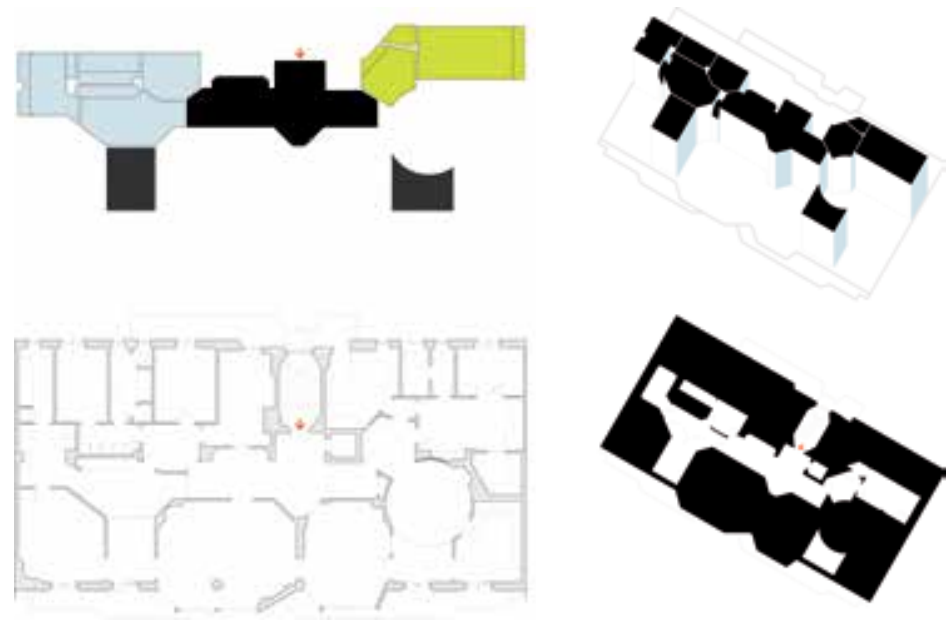

Fig. 12. Planta tipo y esquema de espacios de distribución. Dibujos de la autora.

There is no doubt that, in every residential building, the plan is the fundamental element of the project. However, Caccia also showed us the importance of detail in architecture. His experience as designer and his interest for functional and durability questions kept him close to skilled trades. He was involved in the whole process, changing things and assuming his mistakes during the execution giving a careful service to the client, a concern that goes beyond the work itself. The construction of the building is at the same time solid and light. Above the basement, made of conglomerate stone from Lombardy, we find several types of walling depending on whether they face the bedrooms that occupy the sides of the façade, or the living rooms of each of the apartments, located at the centre and separated by the potent plane of the fireplace. The first one is, we could say, a traditional wall, forty centimeters thick and finished in brown rendering, interrupted by the exits from bedrooms to the balconies. These apertures are framed with volcanic stone doorways whose geometry on one hand allows the maximum light to enter by opening towards the sides and, on the other, recuperate the vertical when closed which ensures good protection against rain water in their upper part. The painted wooden shutters complete these panes, which are perfectly modulated by the shutters open position.

However, in the living rooms the enclosure appears light and modern, like a technical box designed with great precision, in which each piece is perfectly assembled and has its function. Built in iron, the diverse parts solve the views, ventilation, darkening, water collection and so on. The exits to the terraces are located in the areas where the width is bigger, facing west towards Saint Celso. The rest of the windows are orientated to the south and are solved in a functional and logical way. Those that can be cleaned from the balconies are fixed, the rest are sliding and, in both cases, the encounters with the beams are hidden with fixed opal glass, a characteristic element of other works by the author, in this case in a dark red colour. 
Sin embargo, en los estares el cerramiento se presenta ligero y moderno, como una caja técnica diseñada con gran precisión en la que cada pieza esta perfectamente ensamblada y tiene su función. Construido en hierro, las diversas partes solucionan las vistas, la ventilación, el oscurecimiento, la recogida del agua, etc. Las salidas a las terrazas se sitúan en las zonas donde el ancho es mayor, mirando a oeste hacia San Celso. El resto de las ventanas se orientan al sur y se resuelven de un modo funcional y lógico. Aquellas que se pueden limpiar desde las terrazas son fijas, el resto son deslizantes y en ambos casos, el encuentro con los forjados se oculta con vidrios opales fijos, elemento característico de otras obras del autor, en este caso de color rojo oscuro.

El cerramiento incorpora el control del soleamiento mediante unos toldos articulados que en la actualidad todavía funcionan. Las bajantes de pluviales también pertenecen al sistema, de manera que recogen el agua de la cubierta, atraviesan las terrazas y esconden el antipático y difícil encuentro de las carpinterías en las esquinas de los bow-windows. En el vano de la chimenea, el revestimiento de las piezas cerámicas negras refuerza la verticalidad del vacío central. El alzado es, en este punto, la expresión convexa del mundo cóncavo interior, un cuidado estuche que explica la manera propia de proyectar que tiene Caccia en su búsqueda del habitar de dentro a fuera.

Hay que destacar que un año después de la finalización del edificio de la calle Vigoni, en 1960, Caccia construyó un espacio en la XII Triennale de Milán que reproducía uno de los pisos intermedios de esta obra. Dicha Triennale cerró un ciclo histórico. Los miembros del MSA (Movimento Studi di Architettura), (14) del que el formó parte en los primeros años, criticaron el formato de las anteriores Triennales. Entendían que ya no tenía sentido la demostración del arte aplicado a la industria para promover su desarrollo, algo que había llevado a la mostra a un formalismo excesivo. Según el MSA se debía exponer sobre la base de un programa que incidiera sobre los principales problemas de la cultura arquitectónica contemporánea, actuando a través de un órgano de investigación, el Centro di Studi, y revisando, también el carácter de la exposición, tanto en sus espacios como
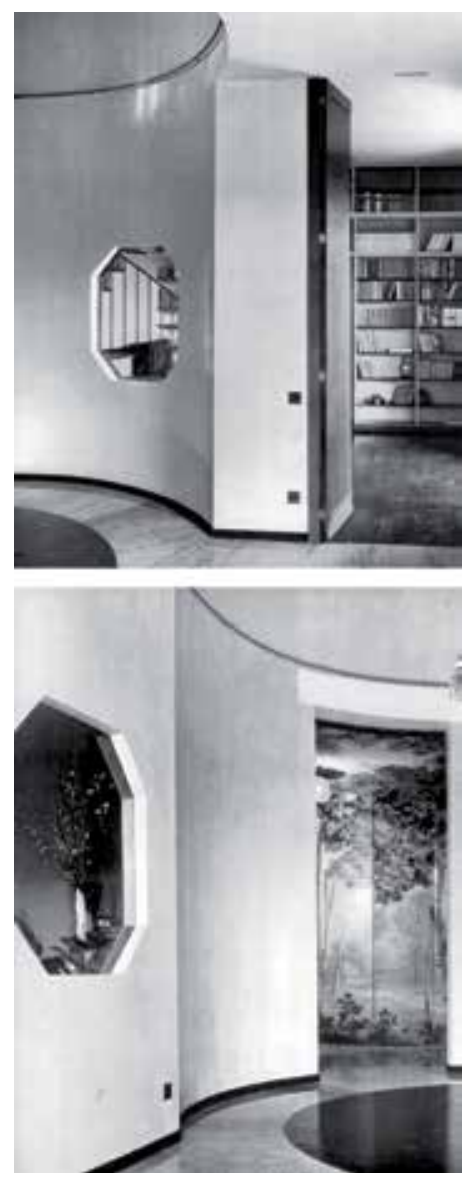

Fig. 13. Distintas vistas del interior de la planta sexta. Domus 380, 1963.

The enclosing incorporates the control of sun light through articulated awnings which still work in the present day. The rain downpipes belong to the system, so that they collect the water from the roof, go through the terraces and hide the obnoxious and difficult encounter of the joineries in the corners of the bow-windows. In the chimney bay the ceramic black tile cladding reinforces the verticality of the central space. At this point, the elevation is the convex expression of the interior concave world, a carefully treated case which explains the particular way that Caccia has of projecting in his search for inhabiting from the inside to the outside.

It has to be pointed out that a year after the completion of the building in Vigoni Street, in 1960, Luigi Caccia Dominioni built a space in the 12th Triennale in Milan which reproduced one of the middle flats of this building. This Triennial closed a historical cycle. The members of MSA (Movimento Studi di Architettura), (14) to which he belonged in the early years, criticised the format of previous Triennales. They understood that it made no sense to display art applied to industry to promote its development anymore, something that had taken the mostra to an excessive formalism. According to the MSA the exhibition should be based on a program that would stress the main problems of contemporary architectural culture, acting through a research group, the Centro di Studi, and similarly revising the character of the exhibition in its spaces as well as its contents. Thus, the 12th Triennale was the first which followed the model of a theme exhibition and whose title was 'House and School. Of the twelve participating countries only five adapted to the new exhibit format, the rest still displayed their objects as mere merchandise once again. The Italian section was constituted by a unitary route which alternated reconstructions of domestic and school spaces, totally furnished, arranged in a way that suggested different possibilities of use for the displayed setting. 
en sus contenidos. De este modo la XII Triennale de Milán fue la primera que siguió el modelo de una exposición temática y cuyo titulo fue 'La casa y la escuela. De las doce naciones participantes, solo cinco se adaptaron al nuevo formato expositivo; el resto siguió mostrando sus objetos como meras mercancías. La sección italiana estaba constituida por un recorrido unitario, que alternaba reconstrucciones de espacios domésticos y escolares totalmente amueblados, dispuestos de modo que sugerían diferentes posibilidades de uso para el ambiente expuesto.

Un año antes de la XII Triennale, en 1959, se clausuró definitivamente en Otterlo el Congreso de los CIAM. La ausencia de los grandes arquitectos del Movimiento Moderno, la interrupción en el panorama arquitectónico del Team x y sobre todo, la crisis de sus postulados que se habían estancado dentro de unas normas academicistas, favorecieron la decisión del cierre. Por ello, es más significativo que Caccia presente la reproducción de uno de los apartamentos, en la que sobre todo se plantea la necesidad de repensar el problema del mínimo habitacional propuesto por el Movimiento Moderno. A través de su edificio de via Vigoni, Caccia quiere mostrar y defender la riqueza de los recorridos interiores, resaltar la necesidad de hacer crecer estos espacios otorgándoles la dimensión simbólica y de tamaño que merecen y crear un bienestar en la vivienda, ya sea grande o pequeña, que vaya más allá de lo meramente funcional, algo que en de algún modo había sido olvidado por el Movimiento Moderno.

El edificio elegido representa la vigencia y sobre todo, la necesaria actualidad de volver a unas planimetrías hechas desde el instinto, que recuperen el uso y la comodidad de ambientes del pasado y que aunque puedan parecer soluciones academicistas, su uso flexible nos acerque mucho a la planta libre, si bien es cierto que la jerarquía de los tránsitos interiores no siempre 'visibles' se adecuan mejor al ámbito de lo doméstico. Por otro lado, el edificio de la calle Vigoni nos enseña a recuperar la importancia de la composición y el detalle de las fachadas, sin dejar de lado el fundamental compromiso que tiene la arquitectura con la historia, con la ciudad y con sus ciudadanos.
Fig. 14. Detalle de fachada. Dibujo de la autora. Fig 15. Martegani, Vincenzo. Detalle de fachada.
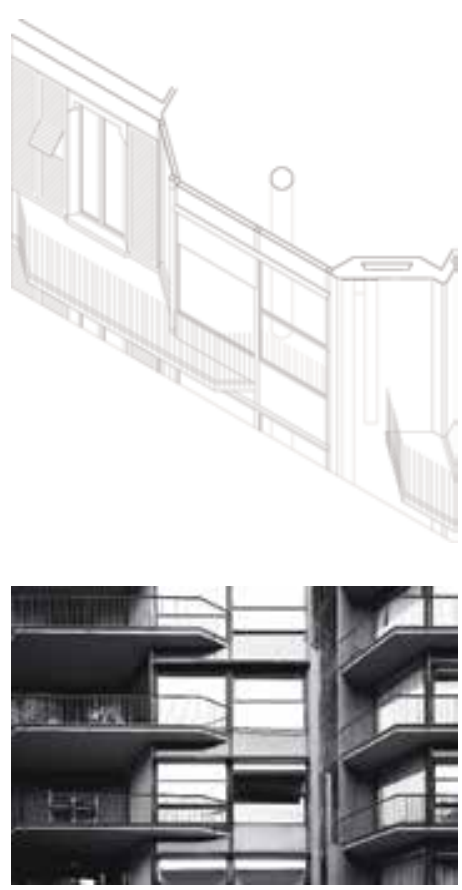

A year before the 12th Triennale, in 1959, the CIAM congress was definitively closed down in Otterlo. The absence of the great architects of the Modern Movement, the emergence of Team x in the architectural panorama and, above all, the crisis of its postulates which had stagnated within the academic norms favoured the decision to close down. Because of this, it is even more significant that LCD presented the reproduction of one of the apartments, in which, above all, he contemplated the need to rethink the problem of the habitable minimum proposed by the Modern Movement. Through his building in via Vigoni, Caccia Dominioni wanted to show and defend the richness of the interior routes, highlight the need to make these spaces bigger and give them the symbolic dimension and size they deserve, and create wellbeing in the home, whether big or small, going beyond the merely functional, something that had been forgotten by the Modern Movement.

The chosen building represents the validity and above all the actual need to go back to surveys made from instinct, which recuperate the use and the comfort of atmospheres from the past and which, although they can seem academic solutions, their flexible use take us much closer to the open plan. However, it is true that the hierarchy of the interior transits that is not always 'visible' adjusts better to the domestic atmosphere. Besides, the building in via Vigoni encourages us to recuperate the importance of composition and detail of the facades, without disregarding the fundamental compromise that architecture has with history, the city and its citizens. 


\section{NOTAS}

1. Desde el siglo XIv el palacio de la familia Caccia Dominioni ha estado situado en el mismo lugar, en el corazón de Milán. Con el paso del tiempo sufrió diversas ampliaciones y restructuraciones. Como consecuencia de los bombardeos de 1943, la crujía que daba a la plaza quedó totalmente destruida; tras finalizar la guerra, en 1947, Caccia se hace cargo de su completa renovación, siendo esta obra su primer proyecto de vivienda en la que define un estilo propio que le acompañará durante toda su carrera.

2. Entrevista concedida por Caccia Dominioni a la revista IoArch Contruzioni e Impianti, 2005.

3. GREGOTTI, Vittorio. Nuevos caminos de la Arquitectura Italiana, Barcelona, 1969.

4. En 1954 Ernesto Nathan Rogers publica el artículo 'La responsabilità verso la tradizione' en el número 202 de la revista Casabella-Continuità, donde defiende el respeto a la tradición mediante la interpretación de la historia, como un modo de retomar la modernidad.

5. En 1959 Reyner Banham inicia, con la publicación del artículo 'Neoliberty. La retirada italiana del Movimiento Moderno', un enfrentamiento entre la revista británica Architectural Review (de la que es editor) y la italiana Casabella. Animado por dos editoriales de Casabella, en los que se apostaba por una vuelta hacia la arquitectura inmediatamente anterior al período de las vanguardias, Banham defiende los valores de la Modernidad y considera la postura de Rogers como una "regresión infantil". Rogers contestará a través de la editorial de Casabella titulada 'La evolución de la arquitectura. Respuesta al guardián de los frigoríficos', donde de nuevo, recrimina a Banham su postura formalista.

6. En 1945, Bruno Zevi, antifascista y arquitecto comprometido social y políticamente, funda la revista Metron y publica el libro Hacia una Arquitectura Orgánica, contribución fundamental a la crítica y crónica de la historia más reciente de esos años, además de defensora de lo orgánico frente al Racionalismo. A principios de los años cincuenta surge una aspiración al Nuevo Realismo, el Neo-realismo, una aproximación a la realidad como historia y como tradición. En Roma tomó especial interés la insistencia del detalle constructivo con la aparición del Manuale dell' Architetto de Mario Ridolfi. Sin duda, Caccia fue conocedor de estas obras.

7. La obra de Caccia empieza a publicarse en las mejores revistas del momento al poco de terminar sus estudios universitarios. Con la aparición en 1941 de la revista Stile, liderada por Giuseppe Botoni, se publican en los primeros números algunas obras de Caccia. Será en el número 3 donde Gio Ponti hable por primera vez del tan renombrado "stile di Caccia". Con la aparición de las
NOTES

1. Since the 14th century the palace of the Caccia Dominioni has been located in the same place in the heart of Milan. As time went by it underwent several extensions and restructuring. As a consequence of the bombings in 1943 the bay that faced the square was totally destroyed and when the war was over, in 1947 , LCD took charge of its complete renovation. This work became his first housing project and he defined in it his own style which would accompany him during his whole career.

2. Interview given by LCD to the magazine IoArch Contruzioni e Impianti, 2005

3. GREGOTTI, Vittorio. Nuevos caminos de la Arquitectura italiana.

Barcelona, 1969.

4. In 1954 Ernesto Nathan Rogers published the article 'Responsibility towards Tradition' in issue number 202 of the magazine Casabella-continuità, where he defendeds the respect for tradition through the interpretation of history, as a way of resuming modernity.

5. In 1959 Reyner Banham initiated, with the publication of the article 'Neoliberty. The Italian Retreat from Modern Architecture', a confrontation between the British magazine Architectural Review (of which he was the editor) and the Italian Casabella. Animated by two Casabella editorials where they positioned for a return to the architecture immediately prior to the vanguards period, Banham defended the values of Modernity and considered Rogers' posture as an "infantile regression". Rogers answered through an editorial in Casabella titled 'The Evolution of Architecture.

Answer to the guardian of refrigerators' where he reproached Banham for his formalist position.

6. In 1945, Bruno Zevi, an anti-fascist and a socially and politically committed architect, founded the magazine Metron and published the book 'Towards an Organic Architecture, fundamental contribution for the criticism and chronicle of the most recent history of those years, besides defending the organic in opposition to rationalism. At the beginning of the fifties an aspiration to the New Realism emerged, the Neo-realism, an approximation to reality as history and as tradition. In Rome the insistence on the constructive detail received special interest with the apparition of the Manuale dell' Architetto by Mario Ridolfi. No doubt LCD knew about these publications. 7. LCD's work started to get published in the best magazines of the time shortly after finishing his university degree. In 1941, with the apparition of Stile magazine, headed by Giuseppe Botoni, some works by Caccia were included in the first issues. Issue number 3 is where Gio Ponti writes for the first time about the well renowned "Stile di Caccia". With the apparition of
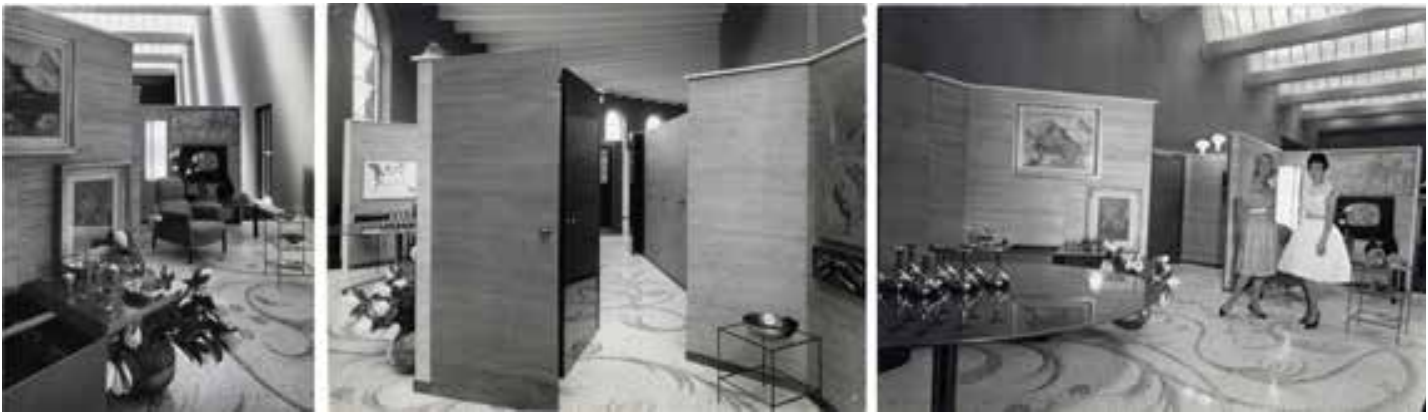

Fig. 16. Vistas del espacio ejecutado por LCD en la XII Triennale. Archivo Fotografico La Triennale di Milan. 
revistas Spazio en 1950 y Casabella-Continuità en 1953, las publicaciones de arquitectura adoptan una marcada dimensión intelectual que va a influir en toda una generación de arquitectos. Sus dos directores, Luigi Moretti y Ernesto N. Rogers respectivamente, publican las obras más notables de Caccia en esos años, en las que podemos encontrar desde el plano de situación hasta las planimetrías o detalles constructivos, en un claro esfuerzo didáctico de mostrar el buen hacer de los arquitectos elegidos.

8. En los primeros días de agosto de 1943 los aliados bombardearon el corazón de Milán. El cincuenta por ciento de la ciudad fue destruida y 250.000 habitantes se quedaron sin hogar.

9. ARNHEIM, Rudolf. Arte y percepción visual.

10. El significado del término poché sería de manera sencilla explicar como el relleno de los muros, a fin de significar en la planta aquello que interesa. Para más desarrollo ver CASTELLANOS Gómez, Raúl. Plan Poché. Madrid, 2012. p. 17.

11. Las estancias enfilade se refieren a una sucesión de espacios o habitaciones formalmente alineadas entre sí, lo que favorece la perspectiva y la visión lejana y fue característica de la arquitectura palaciega durante el periodo barroco.

12. Citado en: CASTELLANOS Gómez, Raúl. Plan Poché. Madrid, 2012. p. 45. 13. "La habitación multifuncional es posiblemente la respuesta más auténtica al arquitecto moderno preocupado por la flexibilidad. La habitación con un propósito genérico, en lugar de específico y con muebles movibles, en lugar de tabiques movibles fomenta una flexibilidad perceptiva, en lugar de una flexibilidad física, lo que permite la rigidez y la permanencia que todavía son necesarias en nuestros edificios. La ambigüedad válida fomenta la flexibilidad útil". VENTURI, Robert. Complejidad y contradicción en la arquitectura. Barcelona: Gustavo Gili, 1978. p.53.

14. MSA son las siglas del Movimiento de Estudio para la Arquitectura de Milán, formado por los miembros del Piano AR, responsables de parte del plan para la reconstrucción de Milán y constituido por los arquitectos Franco Albini, Ludovico Belgiojoso, Ezio Cerutti, Piero Bottoni, Ignazio Gardella, Gian Carlo Palanti, Gabriele Mucchi, Enrico Peressutti, Mario Pucci, Aldo Putelli y Ernesto N. Rogers y por arquitectos recién titulados, como Giancarlo De Carlo o Marco Zanuso. the magazines Spazio in 1950 and Casabella-continuià in 1953, architectural publications adopted a noticeable intellectual dimension which would influence a whole generations of architects. Both directors, Luigi Moretti and Ernesto N. Rogers respectively, published LCD's most notable works in those years, in which include everything from the situation plan to the surveys or building details, in a clear effort to show the good work of the chosen architects.

8. During the first days of August in 1943 the allies bombed the heart of Milan. 50 per cent of the city was destroyed and 250.000 inhabitants lost their homes.

9. ARNHEIM, Rudolf. Art and Visual perception.

10. The meaning of the term poché would be simply explained as the filling of walls with the aim of giving meaning to what is interesting on the plan. For more information see CASTELLANOS Gómez, Raúl. Plan Poché. Madrid. 2012. p17.

11. The enfilade halls refer to a succession of spaces or rooms formally aligned between themselves, which favours perspective and far vision, and which was characteristic in architecture during the baroque period.

12. Cited in Raúl CASTELLANOS Gómez, Raúl. Plan Poché. Madrid, 2012. p. 45.

13. "The multi-functional room probably is the most authentic answer for the modern architect concerned with flexibility. The room with a generic purpose instead of specific and with mobile furniture instead of mobile walls encourages perceptive flexibility instead of a physical flexibility which allows rigidity and permanence, which are still necessary in our buildings. Valid ambiguity encourages useful flexibility". VENTURI, Robert. Complexity and Contradiction in Architecture. Barcelona: Gustavo Gili, 1978. p.53. 14. MSA stands for Milan Architecture Study Movement, formed by $A R$ Plan members, responsible for part of the plan for the reconstruction of Milan and constituted by the architects Franco Albini, Ludovico Belgiojoso, Ezio Cerutti, Piero Bottoni, Ignazio Gardella, Gian Carlo Palanti, Gabriele Mucchi, Enrico Peressutti, Mario Pucci, Aldo Putelli and Ernesto N. Rogers and by recently graduated architects, like Giancarlo de Carlo or Marco Zanuso.

\section{REFERENCIAS}

AA.VV., 'Luigi Caccia Dominioni, maestro milanese', Abitare n. 423, diciembre de 2002.

AA.VV., Domus n. 981, junio de 2014, p. 94.

AA.VV., 'Arquitetture di Luigi Caccia Dominini', Arquitettura civile n. 9/10, 2014.

BELLINI, M. REFICE, R. ZANON DAL BO, L. 'I baroni rampanti del Movimento Moderno' Superfici n. 1, marzo de 1961, p. 7.

CACCIA DOMINIONI, L., 'Casa in condominio a Milano'. Casabella-Continuità n. 217, diciembre de 1957, pp 42-47.

CACCIA DOMINIONI, L., 'Studio dei vani di distribuzione in alogio di medio lusso', Casabella-Continuità n. 243, 1960, p. 34.

CRIPPA, M. A., 'Luigi Caccia Dominioni. Flussi, spazi e architettura', Testo of Immagine, Torino, 1996.

DE CARLO, G., Casabella-Continuità n. 207, 1955, pp. 38-49.

GAVAZZI A. GHILOTTI M., 'Luigi Caccia Dominioni', Itinerari di architettura milanese. Milán: Solferino Editore, 2015.

IRACE F., MARINI P. 'Antologia. Luigi Caccia Dominioni', Abitare n. 405, abril de 2001.

KOHN, D., 'Francesco Somaini e Luigi Caccia Dominioni. In movimento', Abitare n. 525, septiembre de 2012.

\section{REFERENCES}

AA.VV., 'Luigi Caccia Dominioni, maestro milanese', Abitare n. 423,

December 2002.

AA.VV., Domus n. 981, June 2014, p. 94.

AA.VV., 'Arquitetture di Luigi Caccia Dominini', Arquitettura civile n. 9/10,

2014.

BELLINI, M. REFICE, R. ZANON DAL BO, L. 'I baroni rampanti del Movimento Moderno' Superfici n. 1, March 1961, p. 7.

CACCIA DOMINIONI, L., 'Casa in condominio a Milano' Casabella-Continuità n. 217, December 1957, pp 42-47.

CACCIA DOMINIONI, L., 'Studio dei vani di distribuzione in alogio di

medio lusso', Casabella-Continuità n. 243, 1960, p. 34.

CRIPPA, M. A., 'Luigi Caccia Dominioni. Flussi, spazi e architettura', Testo o Immagine, Torino, 1996.

DE CARLO, G., Casabella-Continuità n. 207, 1955, pp. 38-49.

GAVAZZI A. GHILOTTI M., 'Luigi Caccia Dominioni', Itinerari di architettura milanese. Milán: Solferino Editore, 2015.

IRACE F., MARINI P. 'Antologia. Luigi Caccia Dominioni', Abitare n. 405, April 2001.

KOHN, D., 'Francesco Somaini e Luigi Caccia Dominioni. In movimento, Abitare n. 525, September 2012 
IRACE F., 'Il fascino discreto dell 'arquitettura. Costruire e abitare secondo Luigi Caccia', Ottagono n. 91, pp. 52-63, 1988.

PONTI, G., 'Stile di Caccia', Stile n. 3, marzo de 1941, pp. 28-33.

ROMANELLI, M., 'Azucena: 40 anni di storia dell'arredo', Domus, n. 723,

1991.

SANTINI, P.C., 'Larchitettura milanese di Caccia Dominioni', Ottagono n. 6, julio de 1967, pp 90-95.

TRIUNVERI, E., 'Caccia Dominioni e Milano, itinerario 131', Domus n. 790, 1997.

VERCELLONI, V., 'Caccia Dominioni o il prestigio del galateo, tono e decoro nei revestimenti milanesi', Superfici n. 1, marzo de 1961, pp. 67-71.

VERCELLONI V., 'Lautoritratto di una classe dirigente: Milano 1860-1970', Controspazio n. 2/3, 1969.
IRACE F., 'Il fascino discreto dell 'arquitettura. Costruire e abitare secondo Luigi Caccia', Ottagono n. 91, pp. 52-63, 1988.

PONTI, G., 'Stile di Caccia', Stile n. 3, March 1941, pp. 28-33.

ROMANELLI, M., 'Azucena: 40 anni di storia dell'arredo', Domus, n. 723,

1991.

SANTINI, P.C., 'Larchitettura milanese di Caccia Dominioni', Ottagono n. 6 , July 1967, pp 90-95.

TRIUNVERI, E., ‘Caccia Dominioni e Milano, itinerario 131', Domus n. 790, 1997.

VERCELLONI, V., 'Caccia Dominioni o il prestigio del galateo, tono e decoro nei revestimenti milanesi', Superfici n. 1, March 1961, pp. 67-71.

VERCELLONI V., 'Lautoritratto di una classe dirigente: Milano 1860-1970', Controspazio n. 2/3, 1969.

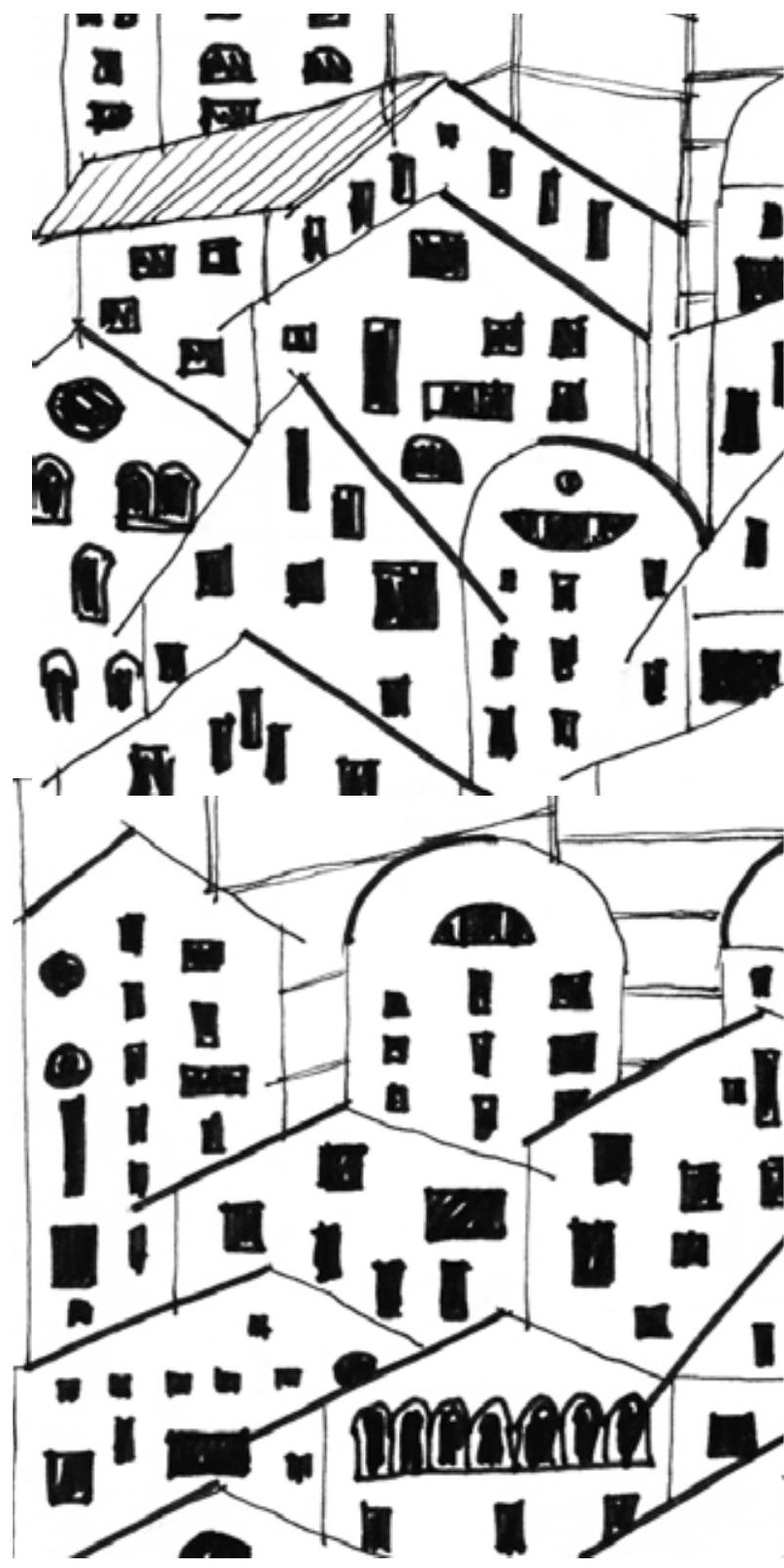




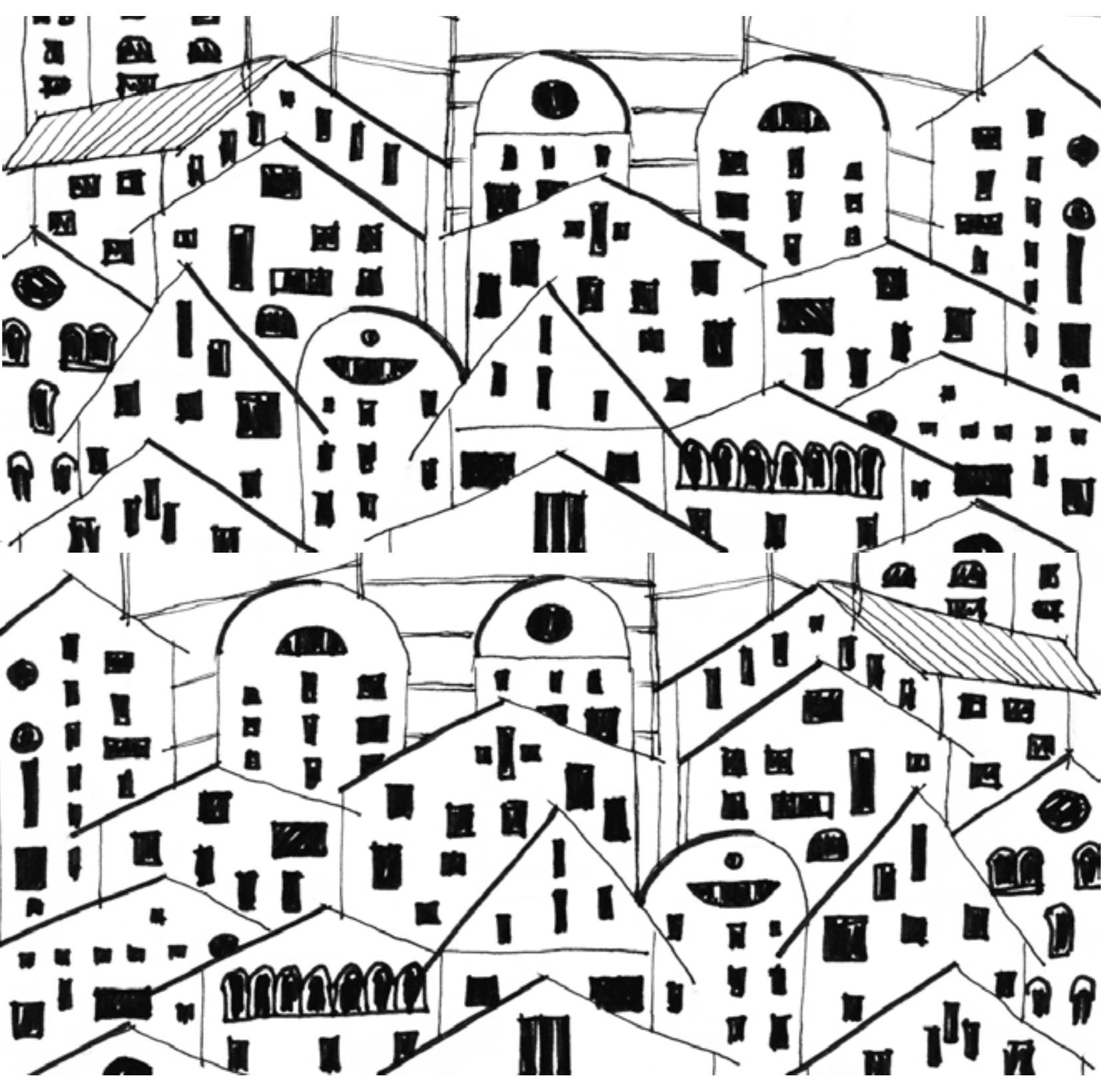

